\title{
Cellular Defects and Altered Gene Expression in PC12 Cells Stably Expressing Mutant Huntingtin
}

\author{
Shi-Hua Li, Anna L. Cheng, He Li, and Xiao-Jiang Li \\ Department of Genetics, Emory University School of Medicine, Atlanta, Georgia 30322
}

\begin{abstract}
Expanded polyglutamine tracts cause huntingtin and other proteins to accumulate and aggregate in neuronal nuclei. Whether the intranuclear aggregation or localization of a polyglutamine protein initiates cellular pathology remains controversial. We established stably transfected pheochromocytoma PC12 cells that express the $\mathrm{N}$-terminal fragment of huntingtin containing 20 (20Q) or 150 (150Q) glutamine residues. The $150 \mathrm{Q}$ protein is predominantly present in the nuclei, whereas the $20 \mathrm{Q}$ protein is distributed throughout the cytoplasm. Electron microscopic examination confirmed that most of the $150 \mathrm{Q}$ protein is diffuse in the nucleus with very few microscopic aggregates observed. Compared with parental PC12 cells and cells expressing 20Q,
\end{abstract}

Expansion of a CAG or glutamine repeat is associated with Huntington's disease (HD) and seven other inherited neurological disorders (MacDonald and Gusella, 1996; Reddy and Housman, 1997; Ross, 1997). Increasing evidence has shown that the expansion of the glutamine repeat causes small protein fragments to accumulate and aggregate in the nucleus of cells. For instance, transgenic mice (Bates mice) expressing exon-1 of the HD gene containing $>115$ CAGs have neuronal intranuclear inclusions even before they develop neurological disorders (Davies et al., 1997). Moreover, intranuclear aggregates containing N-terminal huntingtin fragments have been observed in the brains of HD patients (DiFiglia et al., 1997; Becher et al., 1998; Gutekunst et al., 1999).

The association between HD and nuclear aggregates has led to the idea that such nuclear aggregates are toxic and play a causative role in the pathology of HD. In fact, several studies using cultured cells have showed that nuclear aggregates of polyglutamine proteins are associated with cell death (Cooper et al., 1998; Martindale et al., 1998; Hackam et al., 1999; Moulder et al., 1999). However, other studies show that the nuclear localization of polyglutamine proteins, not the formation of aggregates, is critical for neuronal pathology in transgenic mice (Klement et al., 1998) and in cultured striatal neurons (Saudou et al., 1998). In addition, the regional distribution of intranuclear aggregates in

Received March 10, 1999; revised April 6, 1999; accepted April 7, 1999.

This work was supported by the National Institutes of Health Grant NS36232, the Hereditary Disease Foundation Cure HD initiative, and the Huntington's Disease Society of America. We thank Dr. Steve Hersch for providing electron microscopy facilities and Hong Yi for her technical assistance. We are grateful to Drs. Gillian Bates for providing lambda phage DNAs containing exon- 1 of the HD gene with 20 or 150 CAG repeats, Minoru Yoshida for providing leptomycin B, Moses V. Chao for providing anti-p75 ${ }^{\mathrm{NTR}}$, and Louis Reichardt for providing anti-TrkA/NGF. We also thank Drs. James J. Lah for providing PC12 cells, Douglas Wallace for use of the microplate reader, and Dean Danner for helpful comments on this manuscript.

Correspondence should be addressed to Dr. Xiao-Jiang Li, Department of Genetics, Emory University School of Medicine, 1462 Clifton Road Northeast, Atlanta, GA 30322. E-mail: xiaoli@genetics.emory.edu

Copyright (C) 1999 Society for Neuroscience 0270-6474/99/195159-14\$05.00/0 cells expressing $150 \mathrm{Q}$ display abnormal morphology, lack normal neurite development, die more rapidly, and are more susceptible to apoptotic stimulation. The extent of these cellular defects in $150 \mathrm{Q}$ cells is correlated with the expression level of the $150 \mathrm{Q}$ protein. Differential display PCR and expression studies show that cells expressing $150 \mathrm{Q}$ have altered expression of multiple genes, including those that are important for neurite outgrowth. Our study suggests that mutant huntingtin in the nucleus is able to induce multiple cellular defects by interfering with gene expression even in the absence of aggregation.

Key words: huntingtin; polyglutamine; PC12 cells; nuclear localization; neurite outgrowth; gene transcription

HD brains does not correspond to the neuropathology (DiFiglia et al., 1997; Becher et al., 1998; Gutekunst et al., 1999).

Despite the controversial roles of huntingtin aggregates, it is clear that expanded polyglutamine causes huntingtin to accumulate in the nucleus. Because many transcription factors contain a glutamine-rich domain and the glutamine-rich domain can regulate their activity (Courey and Tjian, 1988; Courey et al., 1989; Gerber et al., 1994), it is likely that expanded polyglutaminecontaining proteins interfere with gene transcription when they are located in the nucleus. This possibility also provides a common mechanism to explain the features that HD shares with other glutamine-repeat diseases.

The above hypothesis can be tested by an HD cell model. Most of the reported cell models have used transient transfection in which the expression levels of transfected protein vary greatly and influence aggregation of the transfected protein and cell viability. A stably transfected cell line that consistently expresses mutant huntingtin in the nucleus will provide a suitable approach to study whether intranuclear huntingtin affects cellular function at the transcriptional level. Examination of stably transfected cell lines by electron microscopy (EM) should also reveal whether intranuclear aggregation of huntingtin is required to induce cellular pathology.

We have established stably transfected rat pheochromocytoma PC12 cells that express the HD exon-1 protein with expanded polyglutamine (150Q). EM examination shows that the majority of transfected mutant huntingtin is diffuse in the nucleus. These cells have defective morphology and decreased viability. Compared with control PC12 cells, cells expressing 150Q have altered expression of multiple genes. Our study suggests that intranuclear huntingtin may alter the gene expression and induce various cellular defects.

\section{MATERIALS AND METHODS}

Antibodies and reagents. A glutathione $S$-transferase (GST) fusion protein antibody, EM48, that is specific to the N-terminal region (amino 
acids 1-256) of human huntingtin was described in our previous studies ( $\mathrm{Li}$ and Li, 1998; Gutekunst et al., 1999). Mouse monoclonal antibody to tubulin (E7) was purchased from the Developmental Studies Hybridoma Bank (Iowa City, IA). Anti-p75 NTR (antibody 9992) was provided by Dr. Moses V. Chao (New York University Medical Center). Anti-TrkA/ nerve growth factor (/NGF) was provided by Dr. Louis Reichardt (University of California, San Francisco). Anti-huntingtin-associated protein (-HAP1) was made in our previous studies (Li et al., 1995). NGF (2.5 S), epidermal growth factor (EGF), cell culture media, and newborn calf serum were obtained from Life Technologies (Gaithersburg, MD). Other reagents used in this study were staurosporine (Sigma, St. Louis, $\mathrm{MO}$ ), ciliary neurotrophic factor (CNTF; Promega, Madison, WI), horse serum (Hyclone, Logan, UT), and Hoechst 33258 (Molecular Probes, Eugene, OR). G418 was obtained from Life Technologies.

Cell cultures. Dr. James J. Lah in the Department of Neurology at Emory University (Atlanta, GA) provided rat pheochromocytoma PC12 cells (Lah and Burry, 1993). PC12 cells were grown in DMEM supplemented with $5 \%$ fetal bovine serum and $10 \%$ horse serum, containing $100 \mu \mathrm{g} / \mathrm{ml}$ penicillin and $100 \mu \mathrm{g} / \mathrm{ml}$ streptomycin, and were incubated at $37^{\circ} \mathrm{C}$ in a humidified $5 \% \mathrm{CO}_{2}$ atmosphere. Cells were grown in dishes or chamber slides (Nunc, Naperville, IL) at densities ranging from 2 to $4 \times$ $10^{4}$ cells $/ \mathrm{cm}^{2}$. The culture media were changed every $48-72 \mathrm{hr}$.

Huntingtin constructs, transfection, and selection of stably transfected cell lines. A partial huntingtin cDNA containing 20 (20Q) or 150 CAG repeats was isolated from a lambda phage DNA that contains exon-1 of the human HD gene [provided by Dr. Gillian Bates (Mangiarini et al., 1996)]. The N-terminal huntingtin fragments encoded by these cDNAs were expressed using the pCIS expression vector that carries a cytomegalovirus promoter ( $\mathrm{Li}$ and $\mathrm{Li}, 1998)$. The pCDNA3 vector, which carries the G418 resistance gene (Invitrogen, San Diego, CA), was cotransfected with the pCIS-huntingtin constructs. Subconfluent PC12 cells in $80 \mathrm{~mm}$ dishes were transfected with $7 \mu \mathrm{g}$ of plasmid DNA and $10 \mu \mathrm{g} / \mathrm{ml}$ lipofectAMINE (Life Technologies) per dish. The transfected cells were then selected in the presence of $500 \mu \mathrm{g} / \mathrm{ml} \mathrm{G} 418$ in DMEM plus $5 \%$ fetal bovine serum and $10 \%$ horse serum. Selected G418-resistant cells were subcloned and maintained in the same conditioned medium until each cell line contained homogenous transfected cells. The expression of transfected huntingtin in PC12 cells was verified by immunofluorescent staining with EM48. After 3-4 months of selection and subcloning, we obtained three cell lines expressing 150Q and five cell lines expressing 20Q. To date, 150Q-9 and 20Q-1 cells have been passaged for $>50$ generations without apparent loss of phenotypes. Cultures were maintained at $37^{\circ} \mathrm{C}$ in a $5 \% \mathrm{CO}_{2}$ incubator, with the medium changed every 48-72 hr. The experiments described here were performed with cloned cells of generation numbers 20-50.

Western blot analysis. Cultured cells were collected and solubilized in SDS sample buffer. Protein samples were then resolved by 10 or $12 \%$ SDS-PAGE. Blots were incubated with EM48 (1:1000), and immunoreactive bands were visualized using a chemiluminescence kit (Amersham, Arlington Heights, IL). EM48 immunoreactivity could be eliminated by overnight preabsorption of the antibody with $20 \mu \mathrm{g} / \mathrm{ml} \mathrm{GST-huntingtin}$ but not GST alone. To assess the protein expression levels quantitatively, we quantified the intensities of the protein bands on the blots using a Personal Densitometer S1 (Molecular Dynamics, Sunnyvale, CA).

Immunofluorescent labeling of cultured cells. Transfected cells grown in chamber slides were fixed in $4 \%$ paraformaldehyde in PBS for $15 \mathrm{~min}$, permeabilized with $0.4 \%$ Triton X-100 in PBS for 30 min, blocked with $5 \%$ normal goat serum (NGS) in PBS for $1 \mathrm{hr}$, and incubated with primary antibodies in $2 \% \mathrm{NGS}$ and PBS overnight at $4^{\circ} \mathrm{C}$. After several washes, the cells were incubated with secondary antibodies conjugated with either FITC or rhodamine (Jackson ImmunoResearch, West Grove, PA). Hoechst dye $(1 \mu \mathrm{g} / \mathrm{ml})$ was used to label the nuclei. A Zeiss fluorescent microscope (Axioskop 2) and video system (Dage-MTI, Michigan City, IN) were used to capture images. The captured images were stored and processed using Adobe Photoshop software.

Electron microscopy. Electron microscopic immunocytochemistry was performed on transfected cells using methods described previously (Li et al., 1997). Briefly, transfected cells were fixed in $4 \%(\mathrm{w} / \mathrm{v})$ paraformaldehyde and $0.2 \%$ glutaraldehyde in $0.1 \mathrm{M}$ phosphate buffer (PB), pH 7.2, for $30 \mathrm{~min}$, permeabilized in $0.05 \%$ Triton X-100 in PBS for $30 \mathrm{~min}$, and preincubated with 5\% NGS in PBS for $1 \mathrm{hr}$. For immunogold labeling, the cells were incubated with primary antibody EM48 (1:1000) and then treated with $1.4 \mathrm{~nm}$ gold-conjugated Fab fragments of goat anti-rabbit IgG (Nanoprobes, Stony Brook, NY) at 1:50 in Tris-buffered saline (TBS), pH 7.2, containing 2\% NGS, silver-enhanced using the IntenSEM kit (Amersham International, Buckinghamshire, England), osmicated $\left(1 \% \mathrm{OsO}_{4} \mathrm{~PB}\right)$, dehydrated, and embedded in Eponate. Ultrathin sections $(60-70 \mathrm{~nm})$ were cut using a Leica Ultracut $\mathrm{S}$ ultramicrotome (Nussloch, Germany). Thin sections were counterstained with 5\% aqueous uranyl acetate for $5 \mathrm{~min}$ followed by Reynolds lead citrate for $5 \mathrm{~min}$ and were examined using a Hitachi H-7500 electron microscope.

For better preservation of the morphology of cells, we fixed some transfected cells with $3 \%$ glutaraldehyde in PB. Ultrathin sections (60-70 $\mathrm{nm}$ ) of these cells were used for electron microscopic examination without immunogold labeling.

Cell death rate and neurite outgrowth assays. Cells were plated at a standard density $\left(4 \times 10^{4} / \mathrm{cm}^{2}\right)$ in six-well plates with DMEM supplemented with 5\% FBS and 10\% horse serum. Cultured cells were harvested, centrifuged at $1000 \mathrm{rpm}$ for $5 \mathrm{~min}$, and resuspended in PBS containing $0.4 \%$ trypan blue. The cells were incubated in the trypan blue solution for $10 \mathrm{~min}$ and transferred to a hemocytometer, and the number of viable (phase bright) and nonviable (blue) cells was recorded. For each sample, cell counts in four corner fields of the hemocytometer were averaged.

To evaluate neurite outgrowth, we plated the cells at low density $(2 \times$ $10^{4}$ cells $/ \mathrm{cm}^{2}$ ) onto six-well plates. Cell cultures were treated with NGF $(100 \mathrm{ng} / \mathrm{ml})$ for $48 \mathrm{hr}$ or with staurosporine (50-100 nM) and EGF (10 $\mathrm{ng} / \mathrm{ml}$ ) for $16 \mathrm{hr}$ and were fixed with $4 \%$ paraformaldehyde in PBS for 15 min. After several washes with PBS, cells with neurites exceeding the cell diameter were counted using an inverted microscope (Olympus Optical CK2, Tokyo, Japan). At the same time, five to seven images $(10 \times)$ were captured by a Pixera camera, and the percentage of cells with neurites was confirmed by analyzing these images. On average, 500-800 cells were counted for each group.

Cell viability and apoptosis assays. Cell viability was determined by a modified 3-(4,5-dimethylthiazol-2-yl)-2,5-diphenyltetrazolium bromide (MTS) assay (Cell Titer 96; Promega), which is based on the conversion of tetrazolium salt 3-(4,5-dimethylthiazol-2-yl)-5-(3-carboxymethoxyphenyl)-2-(4-sulfophenyl) 2- $H$-tetrazolium by mitochondrial dehydrogenase to a formazan product, as measured at an absorbance of $490 \mathrm{~nm}$. PC12 cells were plated in 96-well plates at a density of 10,000 cells/well and maintained 16-24 hr in complete medium. Cells were then changed to medium containing $1 \%$ FBS in the absence or presence of staurosporine at different concentrations. Staurosporine was dissolved in $2 \mathrm{~mm}$ dimethylsulfoxide (DMSO) and diluted in the medium at various concentrations. Leptomycin B (LMB; $10 \mathrm{~nm}$ ) [provided by Dr. Minoru Yoshida (Kudo et al., 1997)] was added to the medium for 12-16 hr. After drug treatment, $20 \mu \mathrm{l}$ of MTS reagent $(2.1 \mathrm{mg} / \mathrm{ml})$ was added to each well. The cells were then incubated for $30-45 \mathrm{~min}$ at $37^{\circ} \mathrm{C}$ in a $5 \% \mathrm{CO}_{2}$ incubator. The reaction was stopped by adding $25 \mu \mathrm{l}$ of $10 \%$ SDS. The plates were read with a microplate reader (SPECTRAmax Plus; Molecular Devices, Palo Alto, CA) at $490 \mathrm{~nm}$. Each data point was obtained using a triplet-well assay.

Apoptosis was measured using a terminal deoxynucleotidyl transferase-mediated biotin-dUTP nick end labeling (TUNEL) assay kit (Promega). Briefly, cells were grown in six-well plates $\left(2 \times 10^{5}\right.$ cells/ well) in complete medium. After $48 \mathrm{hr}$ of culture, cells were collected and centrifuged at $1000 \times g$ for 5 min. Cells were resuspended in PBS with $0.1 \%$ BSA at $1 \times 10^{6}$ cells $/ \mathrm{ml}$. Twenty microliters of the cells mixed with $200 \mu \mathrm{l}$ of PBS and $0.1 \%$ BSA were spun onto a glass slide using a cytospincentrifuge (Shadon Lipshaw, Pittsburgh, PA). Cells were fixed with $4 \%$ paraformaldehyde in PBS for 15 min, permeabilized with $0.2 \%$ Triton X-100 in PBS for $15 \mathrm{~min}$, and then incubated with fluorescentlabeled nucleotide in the presence of terminal deoxynucleotidyl transferase. The cells were then examined using a Zeiss fluorescent microscope (Axioskop 2) and video system. The percentage of apoptotic cells was obtained by counting 600-2000 cells for each group.

Gene expression studies. Wild-type PC12, 20Q-1, and 150Q-9 cells were used for examining their gene expression. Differential display PCR was performed using the GenHunt RNAimage kit (Nashville, TN) and following the manufacturer's instructions. Reverse transcription (RT)-PCR and Northern blot analysis were performed as described previously (S. H. $\mathrm{Li}$ et al., 1998b). Primers for RT-PCR were acgacccttcattgacctc (sense) and gggggctaagcagttggtgg (antisense) for glyceraldehyde-3-phosphate dehydrogenase (GAPDH) (Tso et al., 1985), tgtggaagtgggggatgacg (sense) and gcactcagcaagaaagacct (antisense) for TrkA/NGF (Meakin et al., 1992), ccacattccgacgactgatg (sense) and ccaagaatgagcgcactaac (antisense) for another NGF receptor p75 NTR (Radeke et al., 1987), ggagagcaggacggactttt (sense) and ccagaggggtcatcaatcca (antisense) for metallothionein-II (Andersen et al., 1986), ggttttcattggagggttgc (sense) 


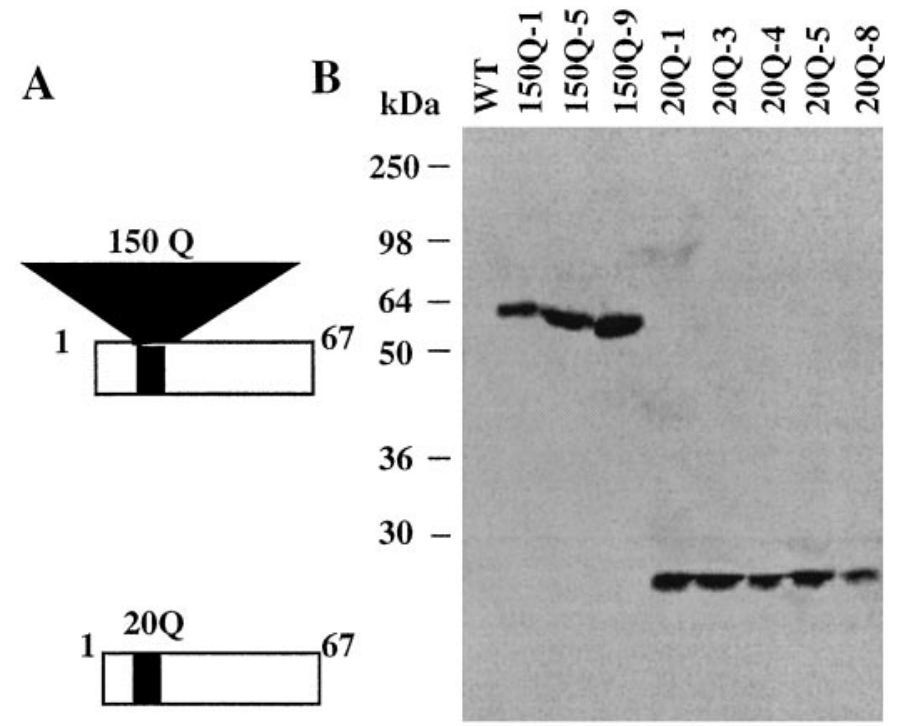

Figure 1. Western blot analysis of stably transfected PC12 cells. A, Schematic structure of truncated huntingtins expressed in PC12 cells. The transfected huntingtin is the huntingtin exon-1 protein with $150(150 \mathrm{Q})$ or 20 (20Q) glutamines and 67 other amino acid residues. $B$, Western blots showing that three cell lines express $150 \mathrm{Q}$ and five cell lines express $20 \mathrm{Q}$. The Western blot was probed with antibody EM48. Note that the expanded polyglutamine of the $150 \mathrm{Q}$ protein greatly hinders its migration in the SDS gel. $W T$, Wild type.

and ctgtctgccacgggtttctc (antisense) for the glutamate transporter GLAST (Tanaka, 1993), and cagcgttgtacgtcttatggg (sense) and ggggattggtccaactgtgg (antisense) for HAP1 (Li et al., 1995). First-strand cDNA was generated from RNA of cultured PC12 cells. PCR conditions were $95^{\circ} \mathrm{C}$ for $45 \mathrm{sec}, 60^{\circ} \mathrm{C}$ for $1 \mathrm{~min}$, and $72^{\circ} \mathrm{C}$ for 2 min with 35 cycles. PCR products were electrophoresed on a $1 \%$ agarose gel.

For Northern blotting, nitrocellulose membranes containing equal amounts of total RNAs from control PC12 cells and transfected PC12 cells were hybridized with $\left[{ }^{32} \mathrm{P}\right] \mathrm{dCTP}$-labeled PCR products obtained with primers as described above. The blots were hybridized in $50 \%$ formamide and $5 \times$ saline-sodium phosphate-EDTA hybridization buffer at $42^{\circ} \mathrm{C}$ and washed with $0.2 \times \mathrm{SSC}$ and $0.5 \%$ SDS at $55^{\circ} \mathrm{C}$ before exposure to x-ray films.

Statistical analysis. All values were expressed as mean \pm SD. Statistical significance was assessed by ANOVA followed by Scheffe's test; $p<0.05$ was considered significant.

\section{RESULTS}

\section{Establishment of stably transfected PC12 cells}

An expanded polyglutamine (115-150 glutamines) has been shown to cause the HD exon-1 protein to form aggregates in the neuronal nucleus in Bates transgenic mice (Davies et al., 1997). A neuronal cell line that expresses the same transgene protein will be valuable to study the effect of mutant huntingtin on neuronal function. We chose to use rat PC12 cells for transfection because this cell line is of neuronal origin and can grow neurites (Greene and Tischler, 1976). We transfected the cDNA of HD exon-1 with 150 CAG repeats into PC12 cells (Fig. 1A). The same DNA fragment with a normal CAG repeat (20Q) was also expressed in PC12 cells and served as a control. Using G418 (500 $\mu \mathrm{g} / \mathrm{ml})$ to select stably transfected PC12 cells, we obtained three independent clones (150Q-1, -5, and -9) that expressed the 150Q mutant HD exon-1 protein and five independent clones (20Q-1, -3, -4, -5, and -8 ) that expressed the 20Q HD exon-1 protein. The expression of transfected huntingtin in these cell lines was confirmed by Western blots (Fig. 1B) using EM48, which recognizes the $\mathrm{N}$-terminal region of huntingtin ( $\mathrm{Li}$ and $\mathrm{Li}, 1998)$. 150Q migrated much slower than 20Q in the SDS gel because it contains an expanded polyglutamine that hinders protein migration (Aronin et al., 1995). Expression levels of $150 \mathrm{Q}$ in the three $150 \mathrm{Q}$ cell lines appeared to be different, and there was also a slight difference in the migration of the transfected 150Qs in the gel (Fig. $1 B)$. The difference in these bands may reflect a small variation in glutamine-repeat numbers, which could result from the instability of the very long CAG repeat in transfected cells.

To determine whether the transfected proteins were overexpressed in these cells, we examined nuclear and cytosolic fractions by Coomassie blue staining. Comparison of the protein profile of the extracts from stably transfected cells and parental PC12 cells did not reveal any additional bands at the same molecular weight as that of $20 \mathrm{Q}$ or $150 \mathrm{Q}$ (data not shown). Thus, it is unlikely that the transfected proteins were expressed at a very high level in stably transfected cells. Because both $20 \mathrm{Q}$ and $150 \mathrm{Q}$ were expressed at a similar level, these cells allowed us to examine cellular defects associated with polyglutamine expansion.

\section{Abnormal morphology and intranuclear huntingtin localization}

20Q-1 and 150Q-5 lines were chosen for extensive characterization of transfected huntingtin in PC12 cells because they have intermediate expression levels. We noticed that the morphology of $150 \mathrm{Q}$ cells was different from that of $20 \mathrm{Q}$ and control PC12 cells. First, $150 \mathrm{Q}$ cells were more likely to clump together, especially when they had been growing for $>36 \mathrm{hr}$, suggesting an increase in cell-cell adhesion after prolonged culturing (Fig. 2, top row). Second, the shapes of the $150 \mathrm{Q}$ cells were not uniform; some were round, but most appeared flattened or polygonal. Most round cells had a diameter of $<15 \mu \mathrm{m}$, which was similar to that of parental PC12 and 20Q cells. However, flattened cells were often $20-30 \mu \mathrm{m}$ in diameter. The appearance of different shapes is unlikely to be attributable to the possibility that the original isolate was not truly clonal; even repeated recloning of the roundest cells still produced the same cell types (data not shown). Instead, characterization of other transfected cell lines has suggested that the cell growth stages and/or the expression of $150 \mathrm{Q}$ may contribute to these various sizes and shapes (see below). Third, most parental PC12 and 20Q cells were round cells with short processes, generally no more than the diameter of the cell body. However, fewer $150 \mathrm{Q}$ cells had processes, and their processes were much shorter (Fig. 2, top row).

Because the expansion of polyglutamine causes huntingtin to localize in the nucleus and to form aggregates in transgenic mice (Davies et al., 1997; Ordway et al., 1997), we examined the subcellular localization of transfected proteins using EM48 immunofluorescence. We found that the majority of the expressed $150 \mathrm{Q}$ was in the nucleus of PC12 cells (Fig. 2). Very intense immunolabeling was seen in the nucleus, and weak labeling was in the cytoplasm of $150 \mathrm{Q}$ cells. The nuclear labeling was further confirmed by staining cells with the nuclear DNA dye Hoechst (Fig. 2). Parental PC12 cells had very weak immunolabeling. Furthermore, 20Q cells displayed intense labeling in the cytoplasm and weak labeling in their nuclei, a pattern that is in striking contrast to that for $150 \mathrm{Q}$ cells. The contrasting distribution of $20 \mathrm{Q}$ and $150 \mathrm{Q}$ clearly indicates that expanded polyglutamine causes huntingtin to accumulate in the nucleus. We also examined other cell lines and found that all the 20Q cell lines had intense cytoplasmic EM48 staining whereas all the 150Q cell lines displayed intense intranuclear EM48 staining (data not shown). 

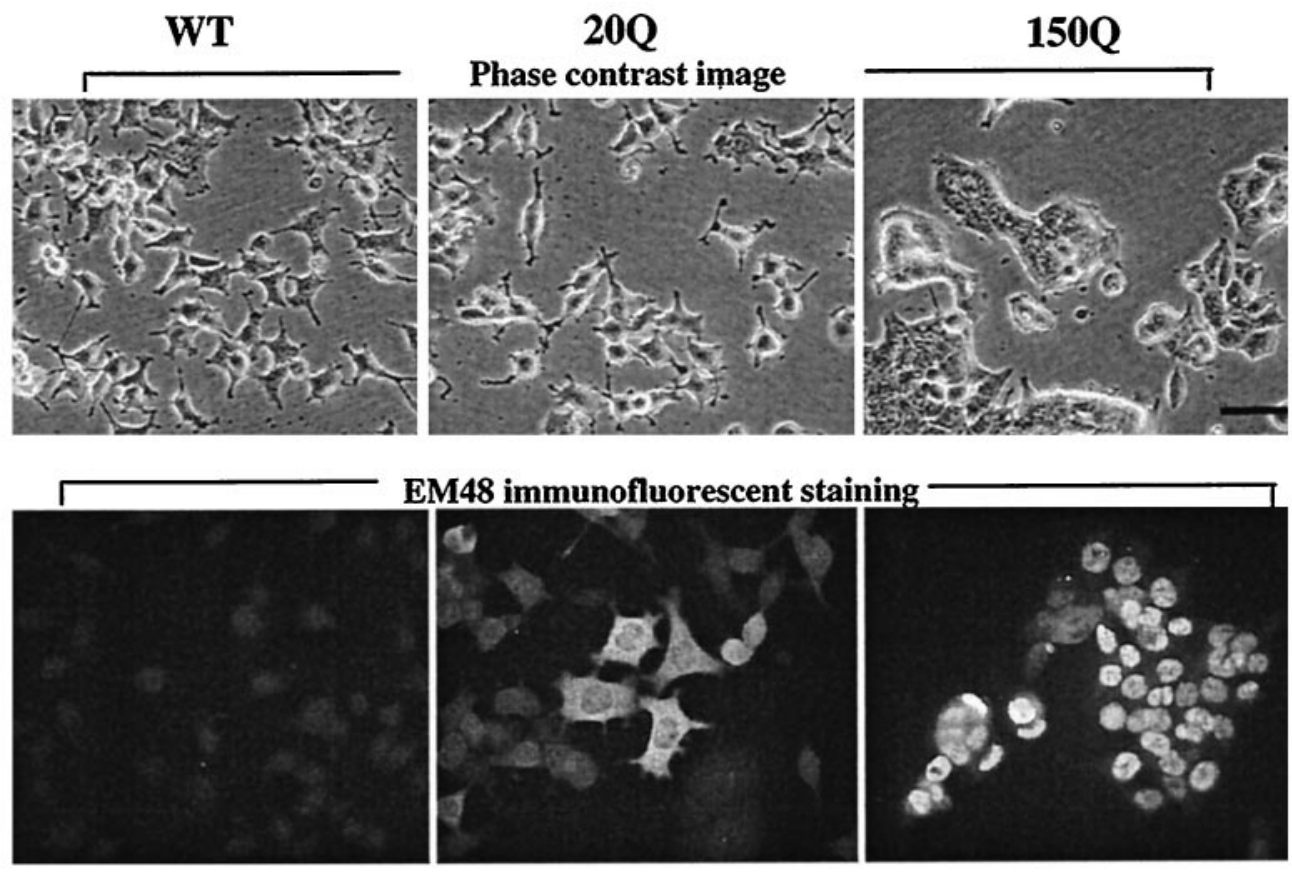

EM48 immunofluorescent staining

Figure 2. Morphology of stably transfected cells and subcellular localization of transfected huntingtin. Top row, Phase contrast images of parental PC12 cells (WT) and 20Q-1 and 150Q-5 cells Note that most of the $150 \mathrm{Q}$ cells are clumped together and have large bodies. Compared with parental PC12 and 20Q cells, $150 \mathrm{Q}$ cells have much shorter processes. Middle row, Immunofluorescent staining showing that the antibody EM48 reacts weakly with endogenous rodent huntingtin in $W T$. EM48 intensely labels the transfected huntingtin in stably transfected PC12 cells that express $20 \mathrm{Q}$ or $150 \mathrm{Q}$ protein. Bottom row, The same cells shown in $B$ stained with Hoechst dye to reveal the nuclei. Note that $20 \mathrm{Q}$ is predominately distributed in the cytoplasm, whereas $150 \mathrm{Q}$ is concentrated in the nucleus. Scale bars: $A, 50$ $\mu \mathrm{m} ; B, C, 10 \mu \mathrm{m}$.
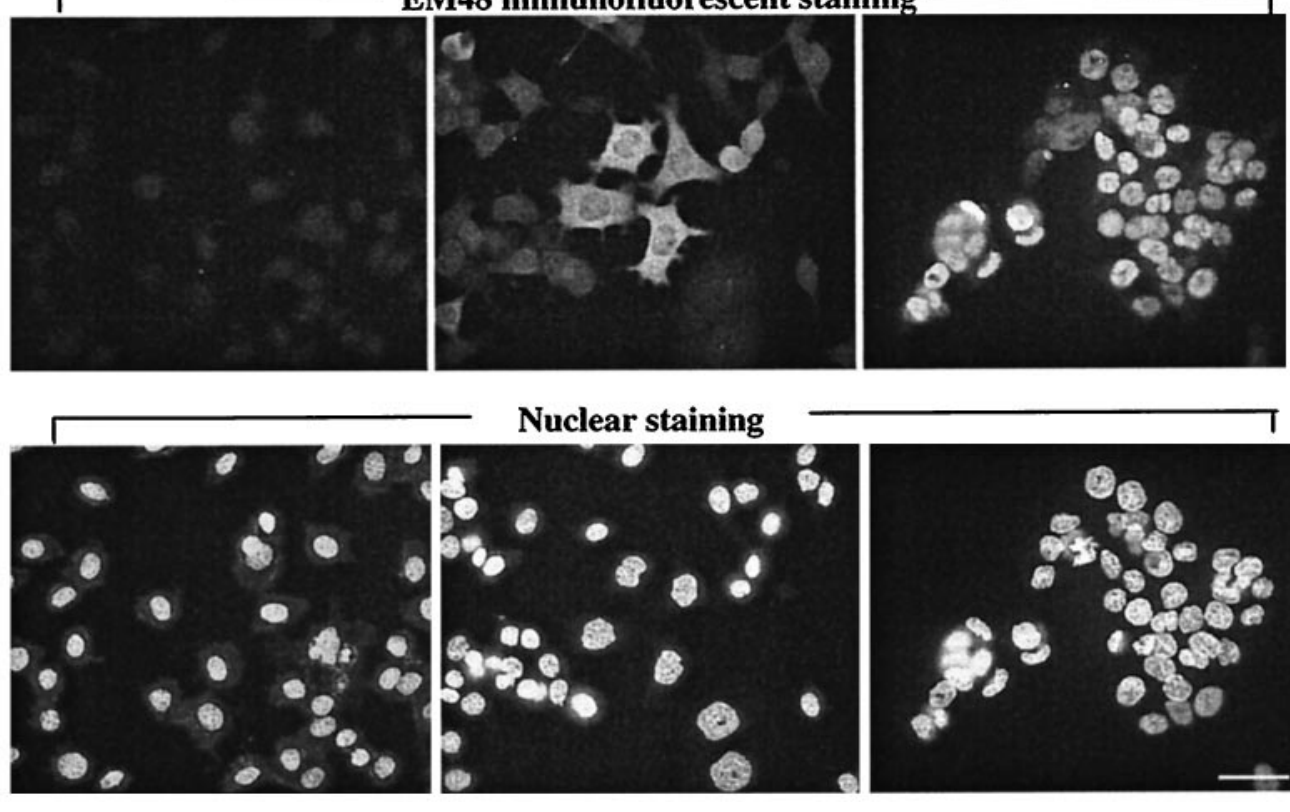

This result confirms that $20 \mathrm{Q}$ and $150 \mathrm{Q}$ were distributed differently in all transfected PC12 cell lines.

It is notable that not all transfected cells had the same intensity of EM48 immunolabeling, perhaps because their stages in the cell cycle influenced the expression level of the transfected protein. A striking finding is that the majority of $150 \mathrm{Q}$ was uniformly diff use in the nucleus and very few cells $(<3 \%)$ had aggregates in their nuclei. It is very likely that the aggregation of huntingtin is time-dependent and that nuclear division during cell proliferation prevents the formation of aggregates.

\section{Electron microscopic examination of $150 Q$ cells}

To confirm the nuclear localization of $150 \mathrm{Q}$ in PC12 cells, we performed electron microscopic examination of ultrathin sections using EM48 immunogold labeling. Most immunogold particles were evenly distributed in the nucleus in $150 \mathrm{Q}$ cells (Fig. $3 A$ ). Almost no immunogold particles were found in the nucleus of control 20Q cells (Fig. 3B). This result confirms that 150Q is indeed enriched in the nucleus and that expanded polyglutamine does cause huntingtin to remain in the nucleus.

We were unable to detect aggregates by immunogold labeling. Because the fixation for immunogold labeling might not preserve the ultrastructure of cultured cells, we performed straight EM examination, with a higher concentration (3\%) of glutaraldehyde and no immunostaining, to identify any aggregates. Using this method, we occasionally observed aggregate-like structures in the nucleus of some cells (Fig. 3C). Less than 3\% of the $150 \mathrm{Q}$ cells had these structures, suggesting that intranuclear aggregates, if any, are very uncommon in these cells. It has been reported that morphological changes within the nuclear membrane, such as indentation, follow the formation of nuclear aggregates in Bates transgenic mice (Davies et al., 1997). We examined 150Q cells that were not dividing and had a single, intact nucleus but saw no notable difference in the nuclear membrane structure of $150 \mathrm{Q}$ cells when compared with that of 20Q and parental PC12 cells (data not shown).

We also examined the ultrastructure of other intracellular structures such as mitochondria, smooth and rough endoplasm reticulum, the Golgi complex, and the plasma membrane. The ultrastructure of all organelles and membranes appeared the same as that in parental PC12 or 20Q cells.

\section{$150 Q$ cells lack the neurite extension response to nerve growth factor}

A distinct neuronal property of PC12 cells is that they can differentiate and grow neurites in response to neurotrophic factors. Interestingly, $150 \mathrm{Q}$ cells were unable to develop normal neurite outgrowth even after treatment with $100 \mathrm{ng} / \mathrm{ml} \mathrm{NGF}$ for 3 d. In contrast, most (75-85\%) 20Q cells, like parental PC12 cells, had long neurites after the same NGF treatment (Fig. 4). The subcellular distribution of transfected proteins in NGFtreated cells was also examined using the EM48 immunofluorescent-staining assay. The result showed that 20Q was expressed in the neuronal processes in differentiated cells, whereas 150Q was 

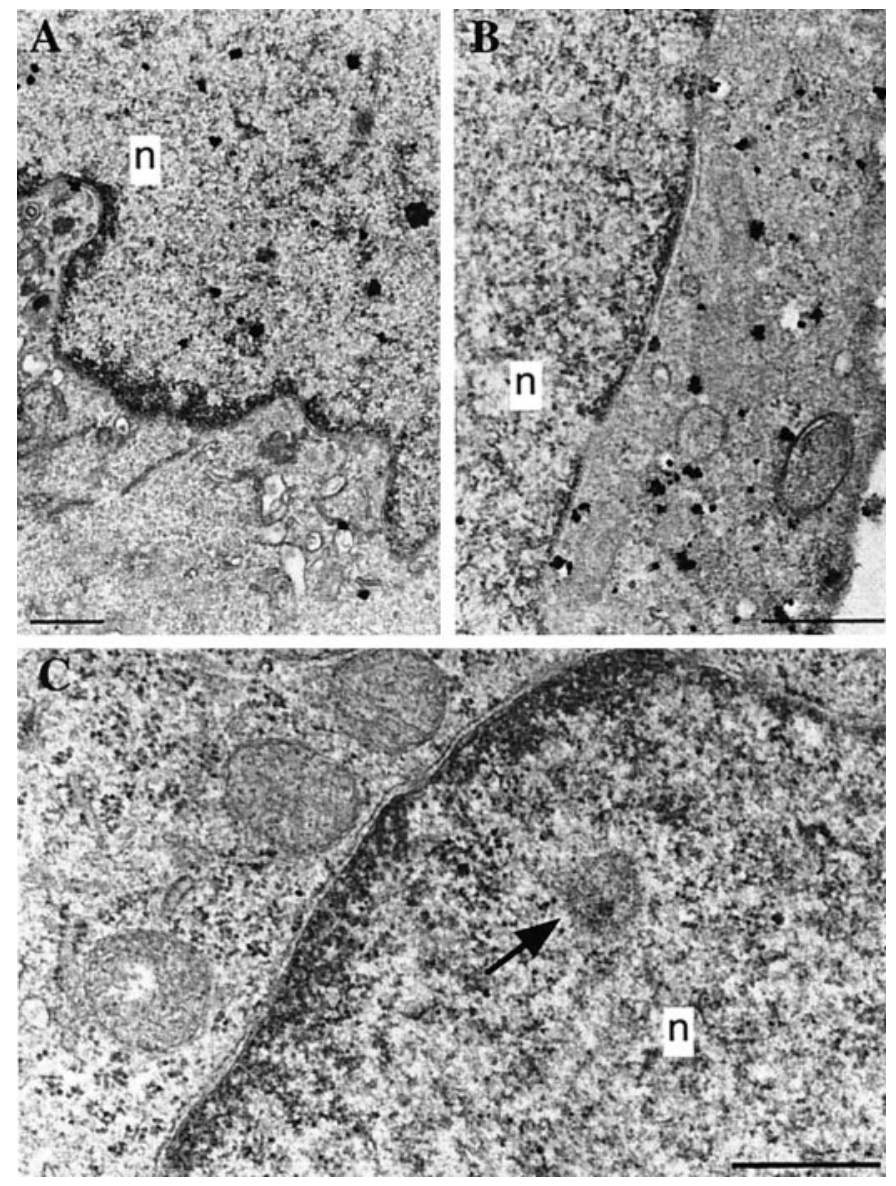

Figure 3. Electron microscopic examination. $A, B$, Electron micrographs of 150Q $(A)$ and 20Q $(B)$ cells labeled by EM48 immunogold show that the majority of immunogold particles are in the nucleus $(n)$ of $150 \mathrm{Q}$ cells $(A)$ and in the cytoplasm of 20Q cells $(B)$. Fewer immunogold particles are in the cytoplasm of $150 \mathrm{Q}$ cells. $C$, To preserve ultrastructure better, we fixed 150Q cells with $3 \%$ glutaraldehyde and examined the cells by electron microscopy without immunolabeling. Note that an aggregate-like structure is present in the nucleus (arrow). Such a structure was found in $<3 \%$ of $150 \mathrm{Q}$ cells and was not found in any control PC12 cells. No obvious structural alteration of the nuclear membrane was observed in $150 \mathrm{Q}$ cells. Scale bars, $0.5 \mu \mathrm{m}$.

still concentrated in the nucleus. The lack of neurites on $150 \mathrm{Q}$ cells was unlikely to be attributable to G418 selection or heterogeneity of parental PC12 cells because all three independent cell lines of 150Q had the same defect in neurite outgrowth, whereas all five 20Q cell lines grew neurite as well as the controls (data not shown). It was also unlikely that these $150 \mathrm{Q}$ cells had lost their neuronal properties because staurosporine, a drug that acts directly on intracellular signaling pathways, could still stimulate neurite extension of $150 \mathrm{Q}$ cells (see below).

We also examined the trophic effects of other growth factors, including interleukin-6 (IL-6; $20 \mathrm{ng} / \mathrm{ml}$ ), CNTF (20 ng/ml), EGF $(10 \mathrm{ng} / \mathrm{ml})$, and basic fibroblast growth factor (bFGF; $20 \mathrm{ng} / \mathrm{ml}$ ). All of these factors act on plasma membrane receptors. CNTF did not promote neurite outgrowth in control PC12 cells. EGF had a very weak effect on neurite extension. IL-6 promoted neurite outgrowth of parental PC12 and 20Q cells, but it had a weaker effect than that of NGF and bFGF. However, all of these trophic factors failed to promote neurite outgrowth in $150 \mathrm{Q}$ cells (data not shown). Thus, in 150Q cells, there might be an impair- ment of a number of membrane receptors or of intracellular signaling pathways.

\section{Staurosporine induces neurite outgrowth of $150 \mathrm{Q}$ cells}

Despite their lack of neurite response to NGF, $150 \mathrm{Q}$ cells were able to develop neurites in the presence of staurosporine (Fig. 5). Staurosporine has been shown to induce neurite outgrowth by its regulation of gene expression (Tischler et al., 1990, 1991; Gollapudi and Neet, 1997; Yao et al., 1997). It also induces apoptosis of cultured cells by inhibiting protein kinases (Koh et al., 1995; Boix et al., 1997). To evaluate both neurite extension and cell death, we treated cells with staurosporine and used a trypan blue exclusion assay. Parental PC12 cells that had been treated with $100 \mathrm{~nm}$ staurosporine grew neurites without displaying significant cell death (Fig. 5A), an observation that is similar to that in a previous report (Yao et al., 1997). However, this concentration of staurosporine killed a significant number of $150 \mathrm{Q}$ cells, although some of the living 150Q cells displayed neurite outgrowth (Fig. $5 B)$. Because the effect of staurosporine on neurite outgrowth could be greatly enhanced by EGF (Raffioni and Bradshaw, 1995), we treated 150 Q cells with EGF and staurosporine together. Interestingly, EGF significantly enhanced neurite outgrowth and reduced cell death (Fig. 5B) (also see below).

\section{$150 Q$ cells are susceptible to apoptotic stimulation}

Because EGF increases the proliferation rather than the differentiation of PC12 cells (Huff et al., 1981), we reasoned that EGF might enhance staurosporine-induced neurite outgrowth by increasing cell viability. To confirm the susceptibility of $150 \mathrm{Q}$ cells to staurosporine, we used the tetrazolium dye (MTS) assay to measure cell viability quantitatively. The $150 \mathrm{Q}$ cells were more susceptible to $10-125 \mathrm{nM}$ staurosporine than were the $20 \mathrm{Q}$ or parental PC12 cells (Fig. 5C). Hoechst dye staining of the nuclei clearly revealed DNA fragmentation in dead 150Q cells (data not shown). Higher doses $(>250 \mathrm{~nm})$ of staurosporine also killed more 20Q cells than parental PC12 cells, supporting the idea that normal N-terminal fragments of huntingtin could also be toxic if they are overexpressed (Hackam et al., 1998). Treating 150 Q cells with EGF (10 $\mathrm{ng} / \mathrm{ml})$ significantly increased cell viability in the presence of 10-100 nm staurosporine (Fig. 5D). Thus, EGF does have a protective effect on staurosporine-induced cell death.

\section{The expression levels of $150 \mathrm{Q}$ and cell death rate}

If $150 \mathrm{Q}$ is associated with the cellular defects we observed in the 150Q-5 line, the expression levels of 150Q should correlate with the extent of the cellular defects. The Western blot result (Fig. $1 B$ ) suggested that the three $150 \mathrm{Q}$ cell lines express different levels of huntingtin. To confirm this, we compared the expression of $150 \mathrm{Q}$ with that of dynactin $\mathrm{P} 150^{\text {Glued }}$ and native huntingtin using Western blotting and densitometry. The ratio of $150 \mathrm{Q}$ to dynactin $\mathrm{P} 150^{\text {Glued }}$ was used to reflect the relative expression level of 150Q. The expression of 150Q was lowest in the 150Q-1 line, intermediate in the 150Q-5 line, and highest in the 150Q-9 line (Fig. 6).

To examine whether $150 \mathrm{Q}$ can cause spontaneous cell death, we measured the viability of the three $150 \mathrm{Q}$ cell lines in the absence of any apoptotic stimulation. Parental PC12 and 20Q cells served as controls. All 150Q cells displayed abnormal morphology; the 150Q-1 line had more small round cells than did the other two lines. In contrast, 150Q-9 cells were generally larger than 150Q-1 and 150Q-5 cells and were more likely to clump together (Fig. 7A). It is likely that varied expression levels of $150 \mathrm{Q}$ account for these differences. To assess the relationship 

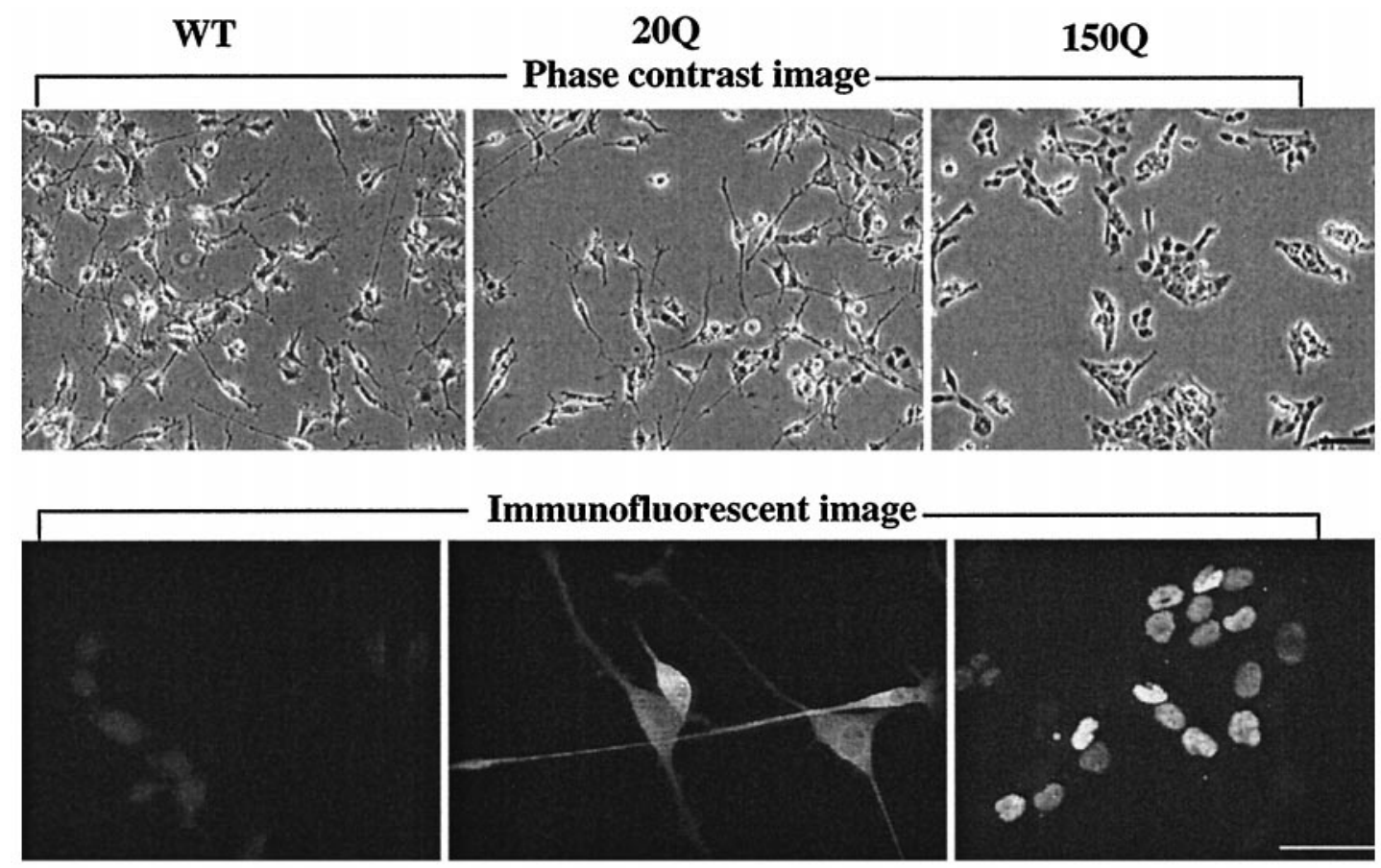

Figure 4. 150Q cells lack the neurite outgrowth response to NGF. Parental (WT) and stably transfected PC12 cells (20Q and 150Q) were treated with NGF $(100 \mathrm{ng} / \mathrm{ml})$ for $48 \mathrm{hr}$. Top row, Low-magnification images showing that both parental PC12 and 20Q cells have long neurites after NGF treatment. 150Q cells, however, lack such neurites. Bottom row, High-magnification images of immunofluorescent staining with EM48. The expressed 20Q is distributed in the cytoplasm and processes, whereas $150 \mathrm{Q}$ is concentrated in the nucleus. Scale bars: top row, $25 \mu \mathrm{m} ;$ bottom row, $10 \mu \mathrm{m}$.

between the expression of $150 \mathrm{Q}$ and cell death quantitatively, we plated the same number of cells and found that $150 \mathrm{Q}$ and control cell lines were growing at similar proliferation rates (data not shown). However, all 150Q cell lines had more dead cells than did control PC12 cells, and the numbers of dead cells were apparently different for the three $150 \mathrm{Q}$ cell lines at various times during culturing (Fig. 7B). The 150Q-9 line had more dead cells than did the 150Q-5 line, which, in turn, had more than did the 150Q-1 line. Thus, the extent of cell death is correlated with the expression level of $150 \mathrm{Q}$ in transfected cells.

To confirm that spontaneous cell death is indeed mediated by an apoptotic mechanism, we used a TUNEL assay to examine apoptotic cells after $48 \mathrm{hr}$ of culture. A significantly greater number of apoptotic cells was found in $150 \mathrm{Q}$ cells than in parental or $20 \mathrm{Q}$ cells (Fig. 7C). Quantitative assessment showed that $1.1 \%$ of $\mathrm{PC} 12,0.9 \%$ of $20 \mathrm{Q}, 6.4 \%$ of $150 \mathrm{Q}-1,9.1 \%$ of $150 \mathrm{Q}-5$, and $25.5 \%$ of $150 \mathrm{Q}-9$ cells underwent apoptosis (Fig. $7 D$ ).

To confirm further that the cell viability is associated with the intranuclear level of $150 \mathrm{Q}$, we treated $150 \mathrm{Q}$ cells with LMB, a drug that blocks nuclear export of RNA and a number of proteins by binding to the nuclear exporting protein CRM1 (Fornerod et al., 1997; Fukuda et al., 1997; Kudo et al., 1997; Ossareh-Nazari et al., 1997; Wolff et al., 1997). After LMB treatment, more 150Q cells had intense intranuclear EM48 labeling than did those without LMB treatment. LMB also increased the nuclear labeling of some 20Q cells (Fig. 8). The result suggests that the HD exon-1 protein may passively diffuse into the nucleus and be exported by LMB-sensitive proteins. How the expanded polyglutamine protein accumulates in the nucleus is unclear. More importantly, more $150 \mathrm{Q}$ cells showed DNA fragmentation after treatment with LMB. In contrast, very few LMB-treated $20 \mathrm{Q}$ cells had DNA fragmentation. This observation was validated by quantitative measurement of cell viability; more 150Q cells than control cells were dying after exposure to LMB (Fig. 8I). The increases in both nuclear $150 \mathrm{Q}$ staining and cell death by LMB suggest that intranuclear huntingtin is associated with cell death.

\section{Intranuclear localization of $150 \mathrm{Q}$ and neurite outgrowth}

To assess the relationship between neurites and the expression levels of $150 \mathrm{Q}$, we treated cells with $100 \mathrm{~nm}$ staurosporine; this concentration of staurosporine induces significant neurite formation in PC12 cells. To prevent cell death, EGF $(10 \mathrm{ng} / \mathrm{ml})$ was used in combination with staurosporine so neurites of $150 \mathrm{Q}$ cells could be maintained.

We evaluated neurite development by measuring the percentage of cells having one or more neurites that exceed one cell body diameter. After staurosporine and EGF treatment, most parental and 20Q cells had long neurites (3-4 cell body diameters). Some $150 \mathrm{Q}$ cells also displayed shorter neurite outgrowth (1-2 body diameters). However, the number of cells with neurites appeared to be different among the three 150Q cell lines. Quantitative analysis showed that $88.1 \%$ of parental PC12 cells and $92.2 \%$ of $20 \mathrm{Q}$ cells had neurites. In contrast, $31.2 \%$ of $150 \mathrm{Q}-1,23.2 \%$ of 150Q-5, and $13.5 \%$ of 150Q-9 cells had neurites (Fig. 9A). Thus, the expression level of $150 \mathrm{Q}$ in these cells was inversely correlated with the number of cells forming neurites.

Staurosporine initiates neurite outgrowth in PC12 cells within a fairly short period of time (4-6 hr) by acting directly on intracellular signaling pathways (Yao et al., 1997). If the initiation of neurite outgrowth by staurosporine is affected by the intranuclear huntingtin concentration, which varies among individual cells because of differences in the cell cycle, we might see that cells with neurites would have less $150 \mathrm{Q}$ in their nuclei than did 
A Staurosporine
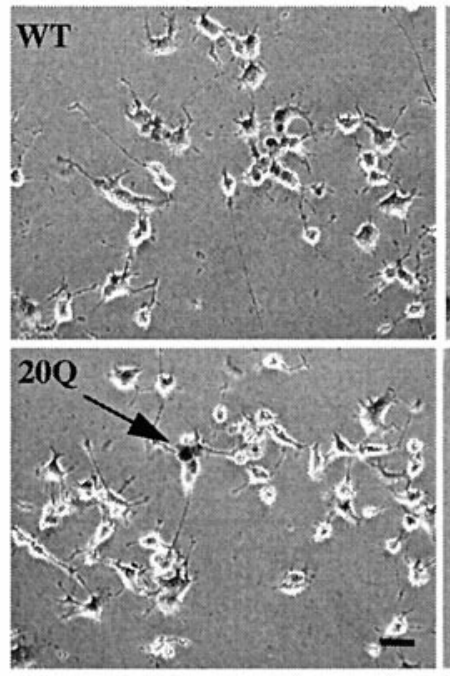

C

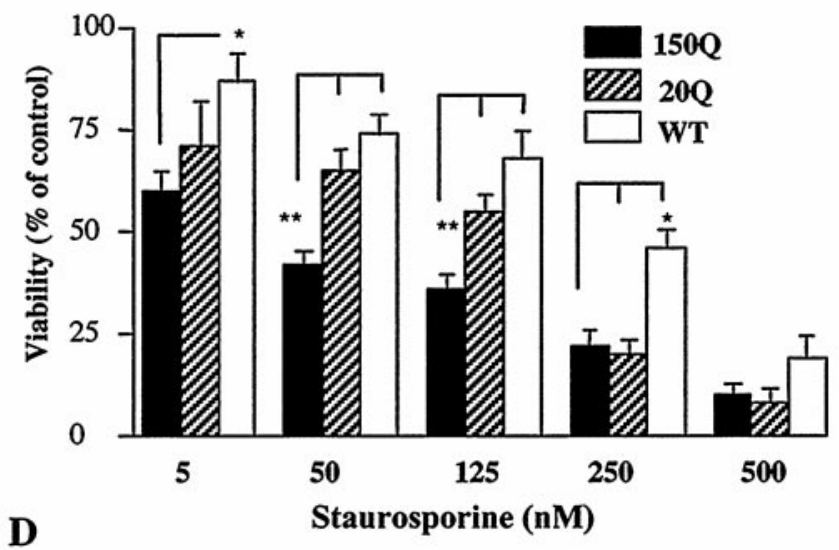

D

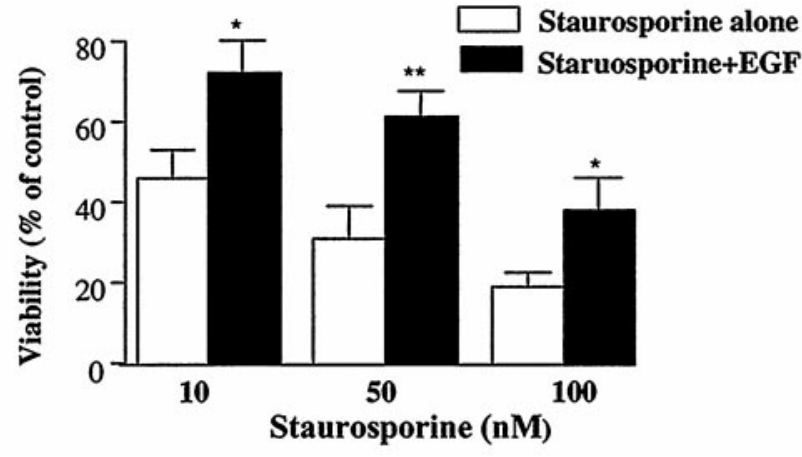

Figure 5. $150 \mathrm{Q}$ cells are more susceptible to apoptotic stimulation by staurosporine. $A, B$, Phase contrast images show that staurosporine (100 nM) kills more $150 \mathrm{Q}$ cells $(B)$ than parental $(W T)$ and 20Q cells $(A)$. Dead cells were stained with trypan blue stain (arrows). $B$, Note that staurosporine also promotes neurite extension and that EGF $(10 \mathrm{ng} / \mathrm{ml})$ decreases the number of dead cells. Scale bars, $25 \mu \mathrm{m}$. $C$, Statistical analysis of cell viability shows that $150 \mathrm{Q}$ cells are more susceptible to staurosporine than are parental and 20Q cells. D, EGF can significantly increase cell viability in the presence of staurosporine. The viability of 150Q cells was examined using the tetrazolium dye (MTS) assay. Cell viability is expressed as the percentage of control. The control is the viability of cells of each group without staurosporine treatment. The data were obtained from three to five independent experiments. Error bars indicate $\mathrm{SD}\left({ }^{*} p<0.05 ;{ }^{*} p<0.01\right)$.
A

B
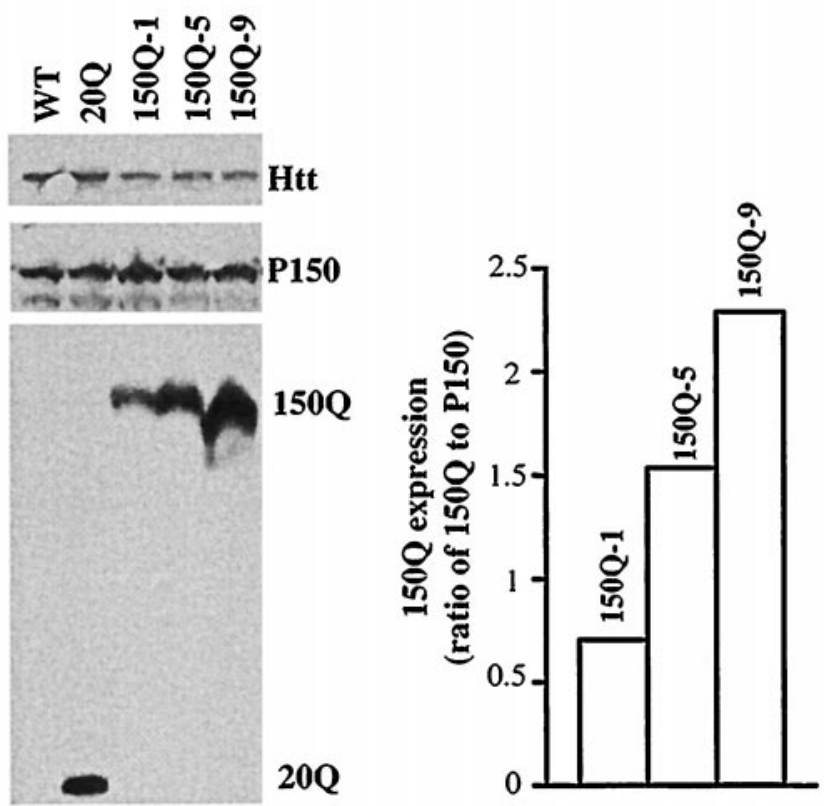

Figure 6. The expression levels of $150 \mathrm{Q}$ in three stably transfected cell lines. $A$, Western blot analysis of the expression levels of $150 \mathrm{Q}$ in comparison with that of native huntingtin $(\mathrm{Htt})$ and dynactin $\mathrm{P} 150^{\text {Glued }}$ $(P 150)$. The $150 \mathrm{Q}$ protein was recognized by EM48. Antibodies to native huntingtin and dynactin $\mathrm{P} 150{ }^{\text {Glued }}$ were described previously (S. H. Li et al., 1998a). B, Quantitative assessment of the expression levels of 150Q in three $150 \mathrm{Q}$ cell lines. The expression level of $150 \mathrm{Q}$ is presented as the ratio of $150 \mathrm{Q}$ to $\mathrm{P} 150$. The data were obtained from two independent experiments. $W T$, Wild type.

cells without neurites. By performing EM48 immunofluorescent staining of $150 \mathrm{Q}$ cells treated with EGF and staurosporine, we observed that most of the cells with neurites displayed much less EM48 labeling in their nuclei than did undifferentiated cells (Fig. $9 B)$. Cells that clumped together and displayed larger body size often had intense intranuclear EM48 labeling. Approximately $87 \%$ of the cells with neurites displayed very weak EM48 staining within their nuclei, whereas only $31 \%$ of the cells without neurites had a similar weak immunolabeling. We also performed immunofluorescent double labeling with EM48 and an antibody to $\alpha$-tubulin. Cells containing tubulin-immunoreactive neurites often displayed weak and diffuse EM48 labeling. Some cells had both intense cytoplasmic and nuclear staining for EM48 (Fig. 9C, arrowhead). However, in cells that did not have long neurites, EM48 immunolabeling was often intense in their nuclei (Fig. 9C). This observation further supports the idea that the presence of $150 \mathrm{Q}$ in the nucleus is associated with the abnormal morphology and lack of neurite growth in PC12 cells.

\section{Altered gene expression in $150 \mathrm{Q}$ cells}

The intranuclear localization of $150 \mathrm{Q}$ prompted us to examine whether it affects gene expression. Its effect on any specific gene may be small, but the combined effects on a number of genes could result in cellular dysfunction. We chose 150Q-9 cells for the study because this cell line has the highest expression level of mutant huntingtin and thus would be most likely to reveal an alteration in the expression of a particular gene. The $20 \mathrm{Q}$ cells served as a control to verify that the altered gene expression is associated with the expanded polyglutamine. To compare the 
$\mathbf{A}$

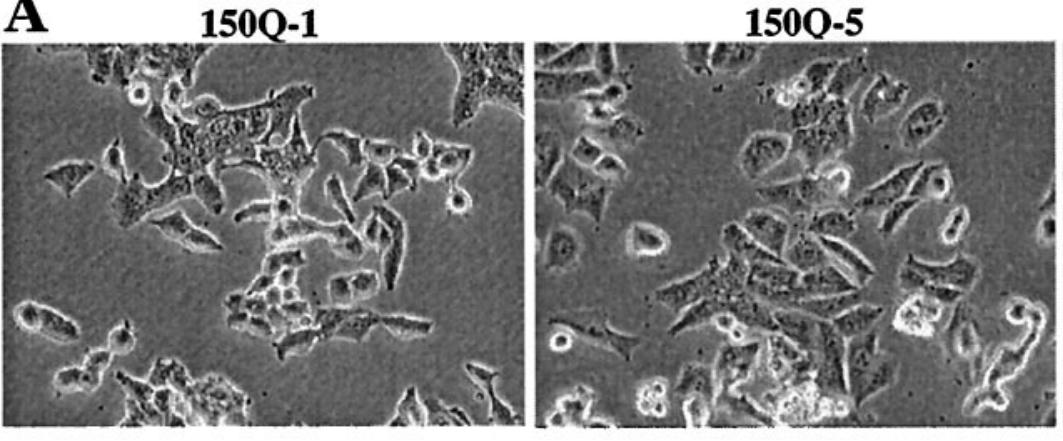

150Q-1

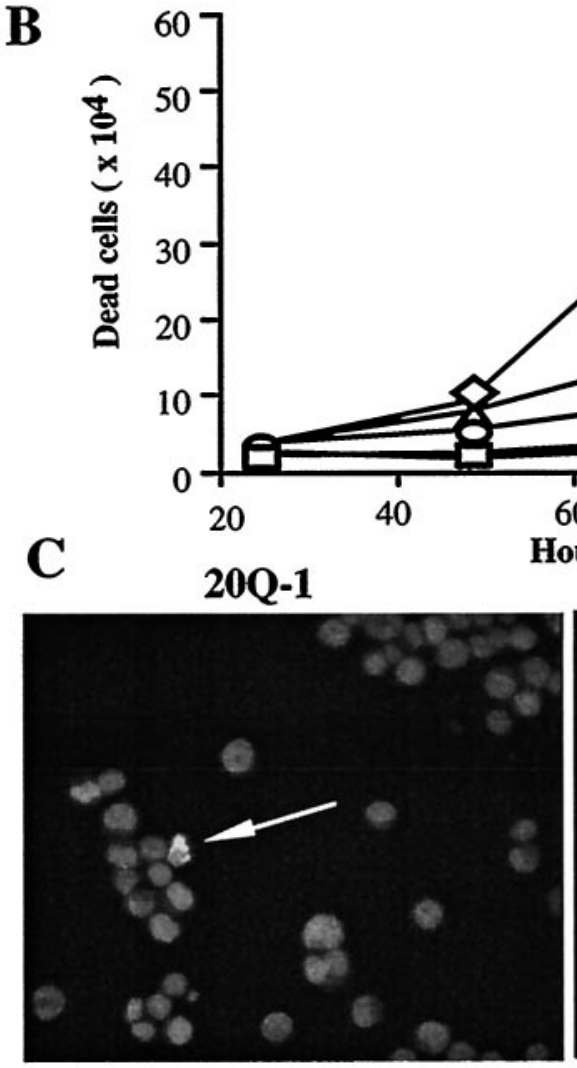

B
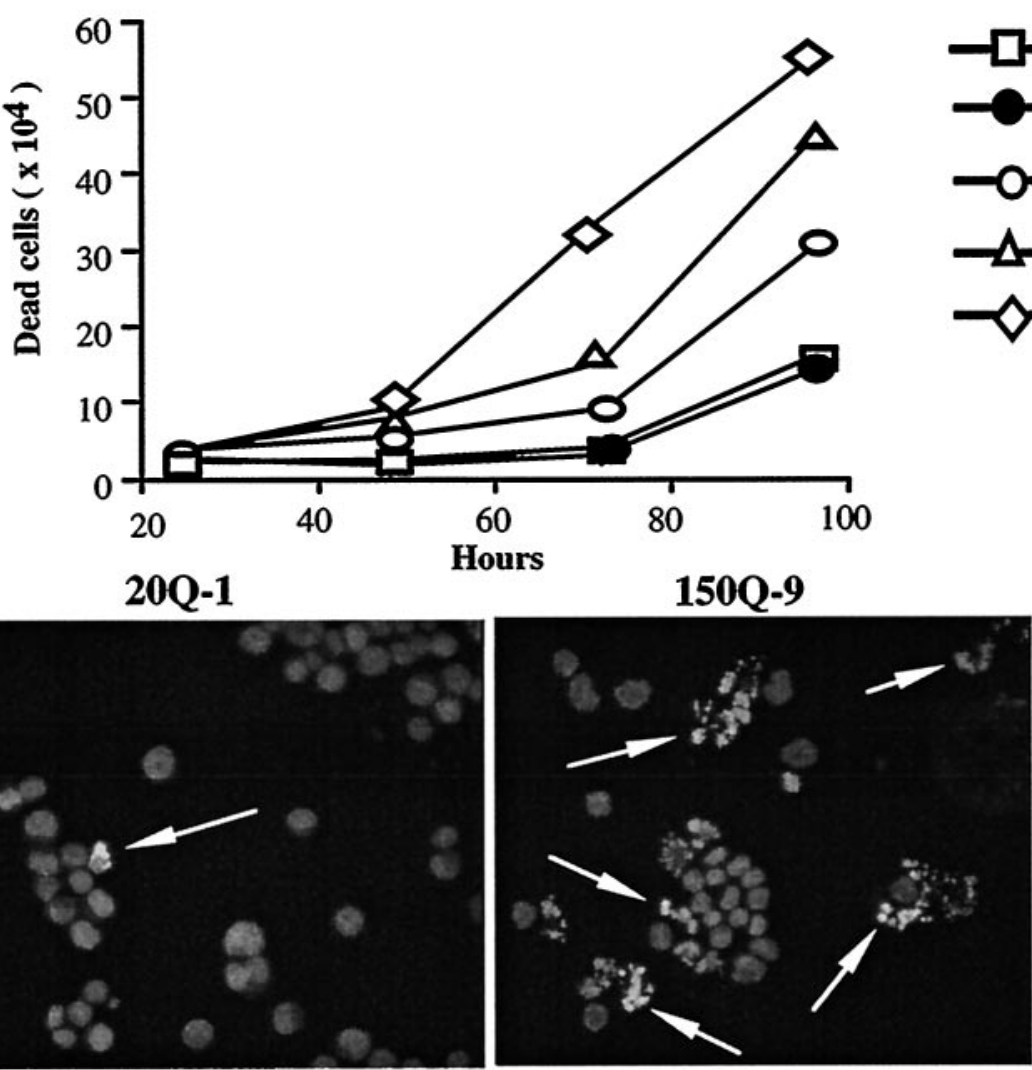
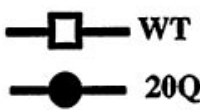

- 150Q-1

$-\triangle-150$ Q-5

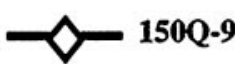

150Q-9
150Q-9

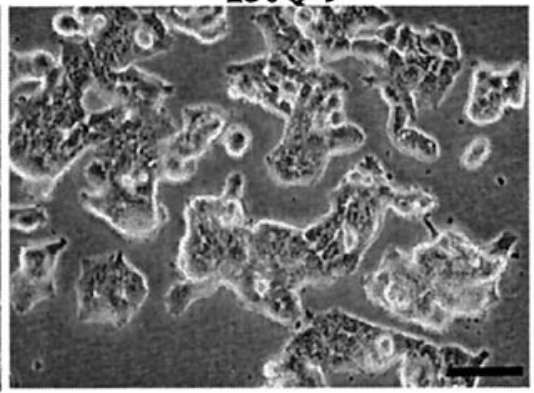

\section{D}

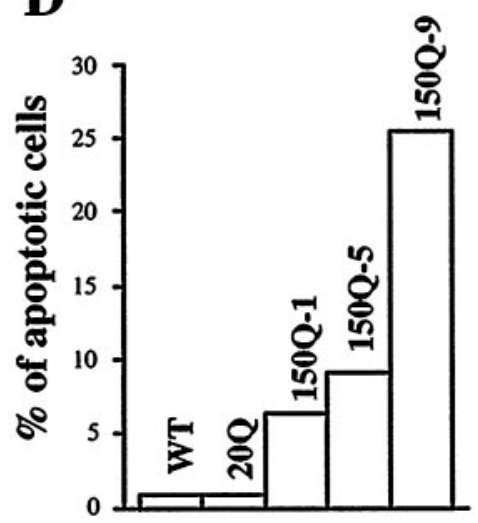

Figure 7. Cell death rate of stably transfected $150 \mathrm{Q}$ cells. $A$, Morphology of three $150 \mathrm{Q}$ cell lines. Note that the $150 \mathrm{Q}-9$ cell line has the most cells that are clumped together. $B$, Dead cells at various times (hours) during culture. The same number $\left(2 \times 10^{4} \mathrm{cells} / \mathrm{cm}^{2}\right)$ of parental, $20 \mathrm{Q}$, and $150 \mathrm{Q}$ cells were plated and cultured up to $96 \mathrm{hr}$. Dead cells were identified using trypan blue and were counted at various times. The data were obtained from two independent experiments. $C$, TUNEL assay showing apoptotic cells (arrows) in 20Q-1 and 150Q-9 lines. $D$, Quantitative assessment of the percentage of apoptotic cells in parental $(W T), 20 \mathrm{Q}$, and three 150Q cell lines. Between 600 and 2000 cells were counted for each data set.

expression of a subset of the total genes expressed in $20 \mathrm{Q}$ and 150Q cells, we used differential display PCR with a set of primers that are reportedly able to screen one-fifth of a cell's total transcripts. We observed 35 PCR products that showed obvious differences in their intensities; some were more intense in the $20 \mathrm{Q}$ samples, whereas some were more intense in the $150 \mathrm{Q}$ samples (Fig. 10A). The altered expression levels of some PCR products in $150 \mathrm{Q}$ cells were confirmed using reverse Northern blotting as suggested by the manufacturer (data not shown). Thus, these PCR products might be derived from transcripts that have different levels in 20Q and 150Q cells.

The genes in 150Q cells that show different expression levels in the differential display PCR might not be readily identified by individual subcloning and sequencing. Because we have observed that $150 \mathrm{Q}$ cells had defective neurite outgrowth in response to NGF, we examined the expression of $\mathrm{p} 75^{\mathrm{NTR}}$, a subunit of the NGF receptor, using RT-PCR with specific primers for $\mathrm{p} 75^{\mathrm{NTR}}$. We also included primers for GAPDH in the same PCR reaction so we could determine whether $\mathrm{p} 75^{\mathrm{NTR}}$ expression is specifically altered in comparison with GAPDH. The result showed that less p $75^{\text {NTR }}$ products were in $150 \mathrm{Q}$ cells than in $20 \mathrm{Q}$ cells (Fig. 10B). To validate this result, we also performed Northern blot analysis. The result showed that transcripts for $\mathrm{p} 75^{\mathrm{NTR}}$ were indeed reduced in 150Q cells compared with wild-type PC12 cells and 20Q cells (Fig. 10C). To see whether our RT-PCR assay also detects altered expression of other genes, we examined the expression of HAP1, a neuronal huntingtin-associated protein that we identified previously and is thought to be involved in neuronal intra- 

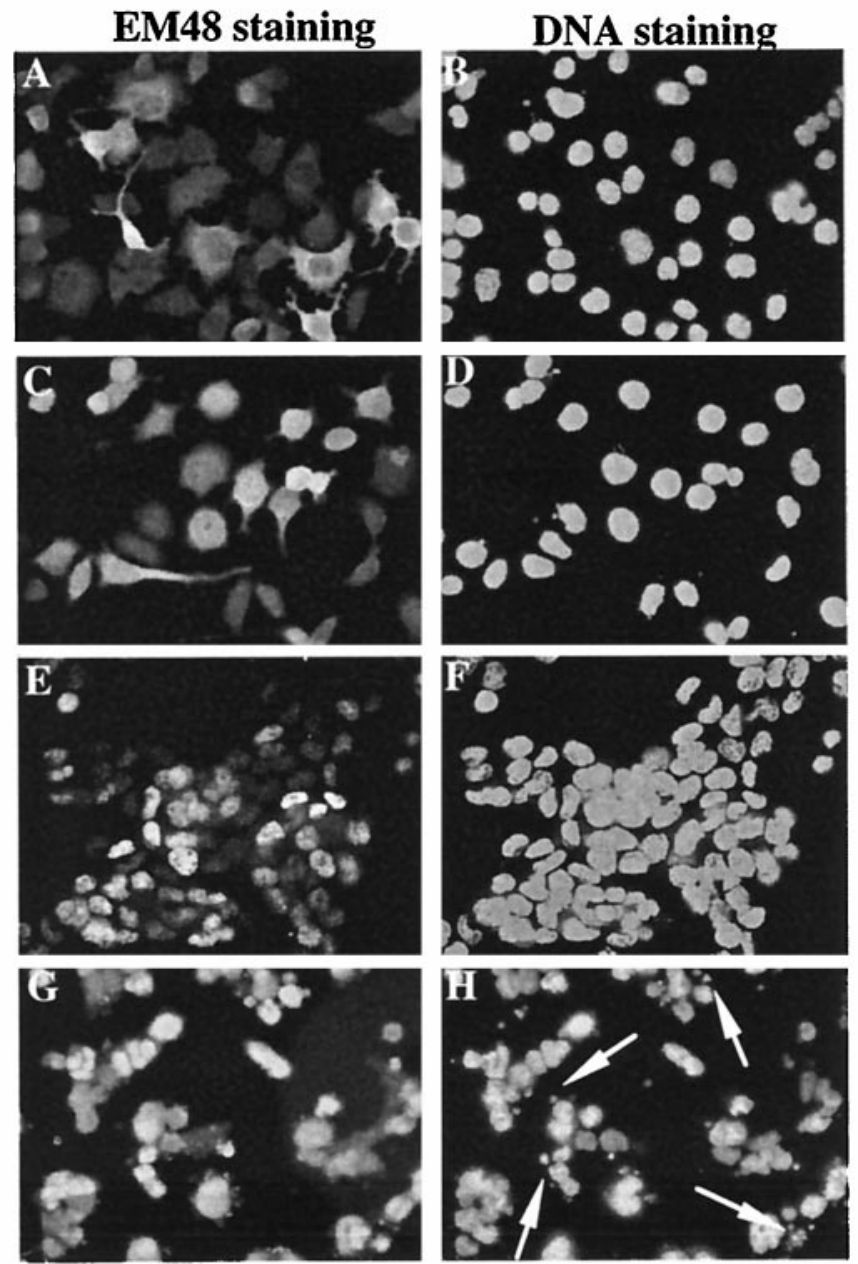

I

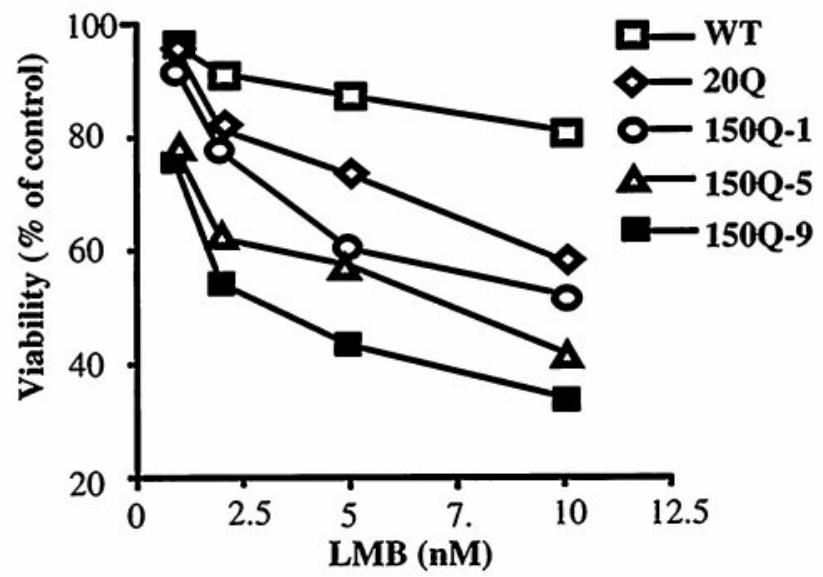

Figure 8. Nuclear distribution of $150 \mathrm{Q}$ and cell death. $A-H$, Examination of $20 \mathrm{Q}(A, B)$ and $150 \mathrm{Q}(E, F)$ cells without treatment compared with 20Q $(C, D)$ and 150Q $(G, H)$ cells treated with the nuclear export inhibitor LMB (5 nM). Cells were stained with EM48 immunocytochemistry $(A, C, E, G)$ and Hoechst $(B, D, F, H)$. Note that intranuclear huntingtin of these transfected PC12 cells could be increased by LMB $(C$, $G)$. LMB-treated $150 \mathrm{Q}$ cells $(H)$ displayed obvious DNA fragmentation (arrows). I, MTS analysis of the viability of wild-type PC12 cells (WT) and $20 \mathrm{Q}$ and $150 \mathrm{Q}$ cell lines after LMB treatment. The percentage of viability is calculated as the viability of treated cells divided by the viability of untreated control cells. The data were obtained from three independent experiments. cellular transport (Engelender et al., 1997; Gutekunst et al., 1998; S. H. Li et al., 1998a; Martin et al., 1999). Both RT-PCR and Northern blot analysis consistently showed a decreased expression of HAP1 in 150Q cells (Fig. 10D).

Because the NGF receptor consists of two peptides, p75 NTR and TrkA/NGF (Chao, 1992; Carter and Lewin, 1997), we also examined the expression of TrkA/NGF transcripts and found that TrkA/NGF expression was also downregulated in 150Q cells (Fig. 10E). Because differential display PCR also suggests that some genes are upregulated in $150 \mathrm{Q}$ cells, we used RT-PCR to examine the expression of two known genes. One is metallothionein-II (MII), a cysteine-rich, heavy metal-binding protein that protects cells from oxidative damage (Karin, 1985; Schwarz et al., 1995). The other is the glutamate transporter (GLAST), a plasma membrane protein for glutamate uptake (Danbolt, 1994). In agreement with their results in the differential display PCR, MII is decreased and GLAST is increased in 150Q cells when compared with the control cells.

It is important to confirm that the level of protein expression of the identified genes is also altered. With available antibodies, we performed Western blotting to examine the protein expression of TrkA/NGF, p75 NTR, and HAP1. Their expression levels were compared with that of tubulin. Consistent with the RT-PCR and Northern blot analyses, Western blotting shows that the expression of TrkA/NGF, p75 NTR, and HAP1 is decreased in 150Q cells in comparison with that in wild-type and 20Q control cells (Fig. $10 F)$. It appears that HAP1's expression is mostly altered in $150 \mathrm{Q}$ cells. Western blot examination of two other $150 \mathrm{Q}$ cell lines, 150Q-1 and 150Q-5, also revealed that HAP1's expression was decreased in these cell lines, although the extent of their decreased expression appeared to be less than that for 150Q-9 cells (data not shown).

\section{DISCUSSION}

One of the goals of these studies was to develop a cell line that models the nuclear accumulation of the mutant huntingtin. This goal was achieved using PC12 cells transfected with the HD exon-1 protein with 150 glutamine repeats. An HD cellular model should have two features: (1) expanded polyglutamine causes huntingtin to accumulate in the nucleus, and (2) the expression of mutant huntingtin is associated with neuronal dysfunction. The cell model we established appears to have these features. First, polyglutamine expansion causes the HD exon-1 protein to accumulate uniformly in the nucleus of PC12 cells. Second, PC12 cells expressing expanded polyglutamine huntingtin display multiple cellular defects including abnormal morphology, high death rate, hypersensitivity to apoptotic stimulation, and defective neurite development. These defects appear to be correlated with the expression level of 150Q in different cell lines. Furthermore, this cell model also provides evidence of the idea that the intranuclear localization of huntingtin affects gene expression.

It is known that only N-terminal huntingtin fragments, which are generated by proteolytic cleavage of full-length huntingtin, are able to enter the nucleus and form aggregates (Hackam et al., 1998; Li and Li, 1998; Martindale et al., 1998). Polyglutamine expansion also causes other disease proteins to enter the nucleus and form aggregates in dentatorubral and pallidoluysian atrophy (Becher et al., 1998; Igarashi et al., 1998), spinal and bulbar muscular atrophy (M. Li et al., 1998), and several forms of spinocerebellar ataxia (Paulson et al., 1997; Skinner et al., 1997; 
A

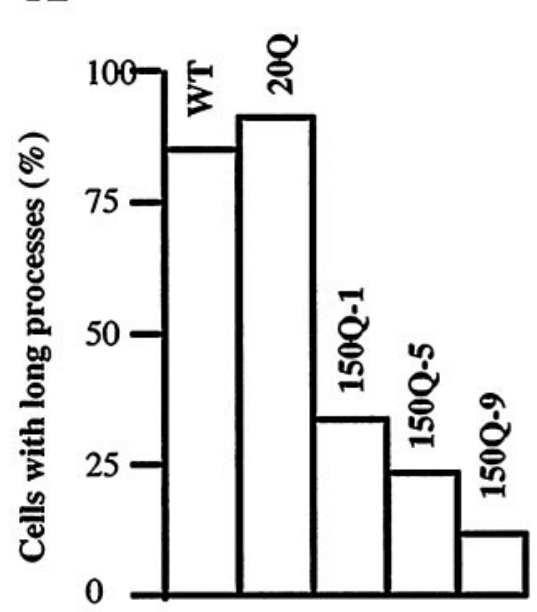

C

\section{Tubulin immunostaining}

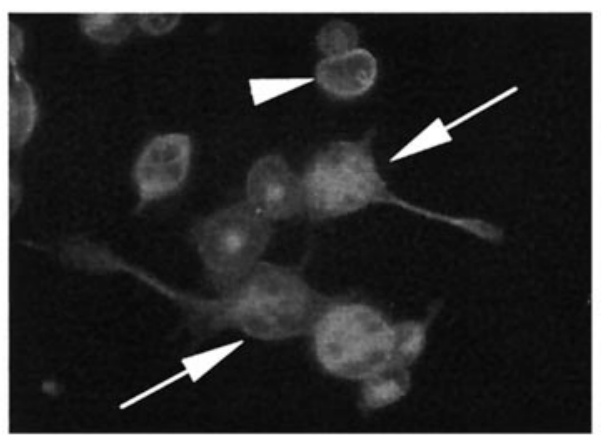

Phase contrast

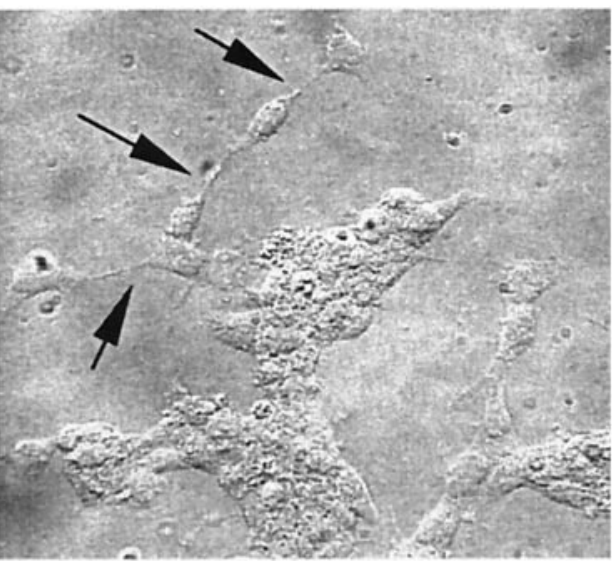

EM48 immunostaining

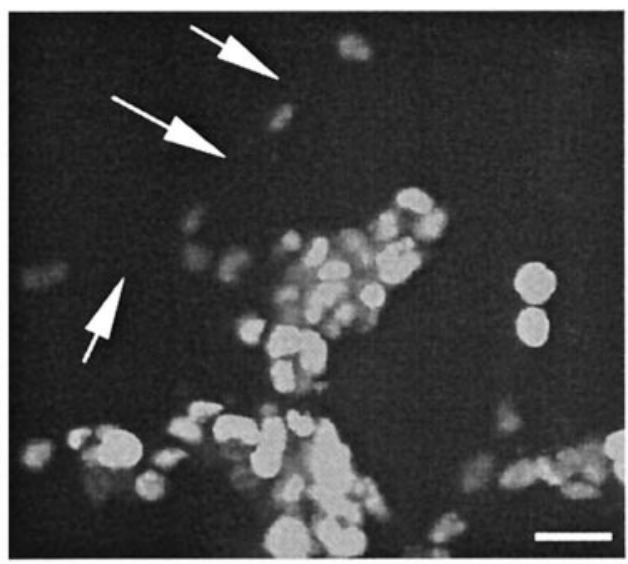

EM48 immunostaining

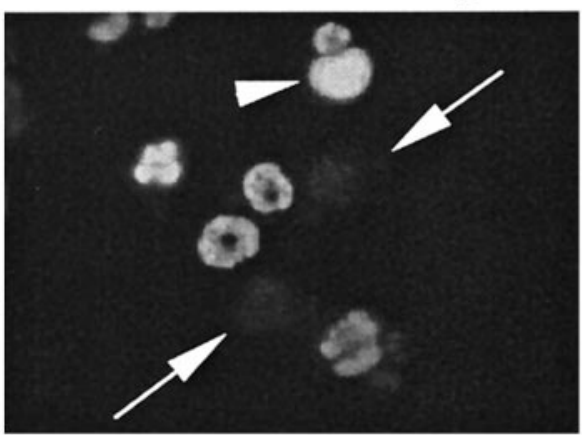

Hoechst staining

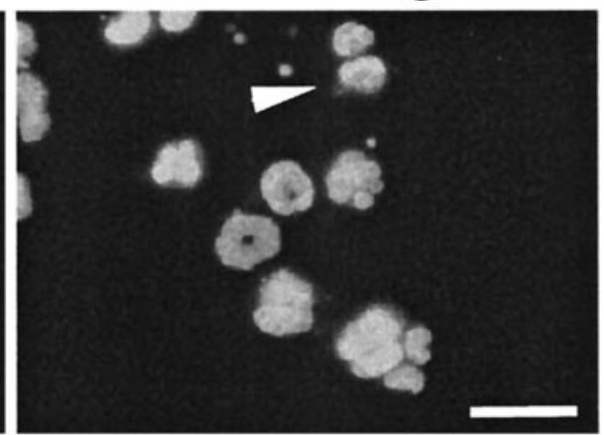

Figure 9. The expression of $150 \mathrm{Q}$ is decreased in cells with neurites. A, Quantitative analysis of the percentage of cells with neurites longer than one cell body diameter. The cells were treated with staurosporine $(100 \mathrm{nM})$ and EGF $(10 \mathrm{ng} / \mathrm{ml})$. The data were obtained from three independent experiments by counting 800-1000 cells for each group. WT, Wild type. $B$, Phase contrast image showing that some of the $150 \mathrm{Q}-5$ cells treated with staurosporine and EGF display neurite outgrowth. The same cells were immunostained with EM48. Note that immunolabeling of $150 \mathrm{Q}$ is less intense in cells having neurites than in the undifferentiated and clumped cells. $C, 150 \mathrm{Q}$ cells doubly immunolabeled with EM48 and the mouse monoclonal antibody against tubulin. Some cells (arrowhead) show both cytoplasmic and nuclear EM48 labeling. Note that cells (arrows) displaying tubulin-immunoreactive neurites have much weaker EM48 labeling than have those without neurites. Hoechst staining was used to reveal the nuclei of these $150 \mathrm{Q}$ cells. Scale bars, $10 \mu \mathrm{m}$.

Holmberg et al., 1998). However, the mechanisms for the nuclear translocation and retention of huntingtin may differ from those for other polyglutamine proteins. For instance, the spinocerebellar ataxia-1 (SCA1) protein ataxin-1 carries a consensus nuclear localization signal (NLS), and deletion of the NLS prevents ataxin-1 from entering the nucleus (Klement et al., 1998). Similarly, the SCA3 protein ataxin-3 also has an NLS, and its nuclear translocation does not require the presence of polyglutamine (Tait et al., 1998). On the other hand, the HD exon-1 protein does not have an NLS; instead, the expansion of the glutamine repeat causes this protein to accumulate in the nucleus. Because fragments of N-terminal huntingtin enter the nucleus more easily, it has been proposed that intranuclear localization of mutant huntingtin may rely on passive diffusion (Hackam et al., 1998). If so, the accumulation of huntingtin with expanded polyglutamine is likely caused by its increased association with nuclear molecules. This possibility is supported by the findings that polyglutamine expansion causes huntingtin to interact avidly with other specific proteins (Li et al., 1995; Trottier et al., 1995; Burke et al., 1996; Sittler et al., 1998). One of these proteins is GAPDH, which is also found to bind to other polyglutamine proteins (Burke et al.,
1996; Koshy et al., 1996) and to be translocated into the nucleus during apoptosis (Sawa et al., 1997; Ishitani et al., 1998; Saunders et al., 1999). It will be interesting to study whether the interaction between GAPDH and 150Q is involved in the nuclear localization of $150 \mathrm{Q}$. It is also equally possible that $150 \mathrm{Q}$ binds more weakly to nuclear exporting proteins than does 20Q. This possibility is supported by our finding that LMB increased intranuclear huntingtin staining.

Our EM study shows that most $150 \mathrm{Q}$ cells had a diff use, nuclear distribution of huntingtin rather than the inclusions or aggregates that are seen in transgenic mice. A recent study showed that the peak appearance of intranuclear aggregates in cultured primary neurons occurs $6 \mathrm{~d}$ after huntingtin transfection (Saudou et al., 1998). However, PC12 cells divide every 2-3 d, which may not be long enough for $150 \mathrm{Q}$ to form aggregates. The aggregation of huntingtin may also depend on protein concentration. This may explain why transient transfection of cultured cells, which often results in protein overexpression, can produce huntingtin aggregates even in dividing cells (Cooper et al., 1998; Li and Li, 1998; Martindale et al., 1998). It is also possible that cells having huntingtin aggregates may not be able to survive during stable 

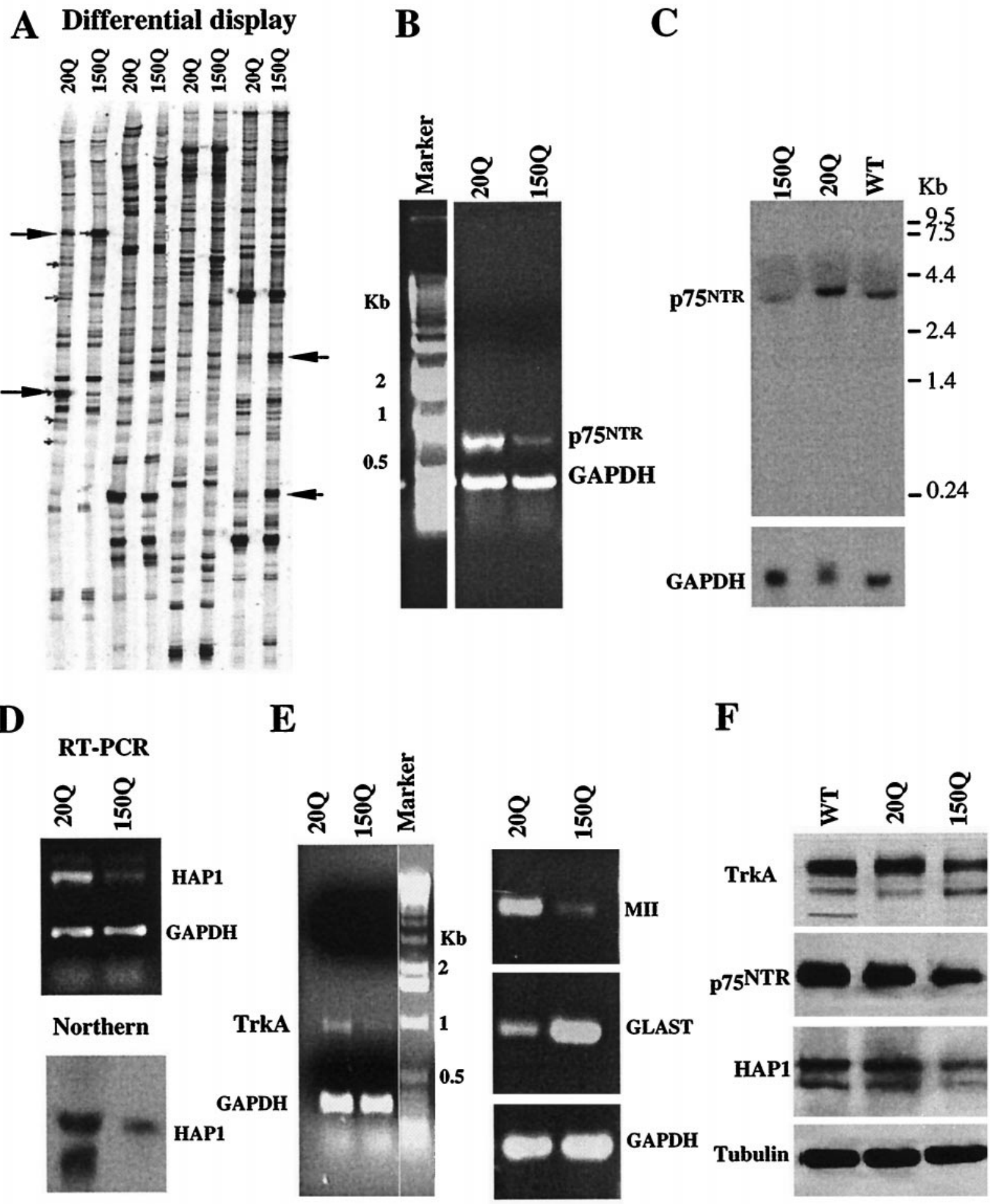

Figure 10. Altered gene expression in 150Q cells. A, Differential display PCR of 20Q and 150Q cells. Arrows indicate bands that show different intensities. $B$, RT-PCR analysis of the NGF receptor subunit $\mathrm{p} 75^{\mathrm{NTR}}$ in $20 \mathrm{Q}$ and $150 \mathrm{Q}$ cells. PCR reactions contained primers for $\mathrm{p} 75^{\mathrm{NTR}}$ and GAPDH. PCR products were resolved on a $1 \%$ agarose gel. $C$, Northern blot analysis of the expression of $\mathrm{p}^{2} 5^{\mathrm{NTR}}$ in wild-type (WT), 20Q, and $150 \mathrm{Q}$ cells. The blot was also hybridized with GAPDH cDNA probe. D, RT-PCR (top) and Northern blot (bottom) analyses of HAP1 expression in $20 \mathrm{Q}$ and $150 \mathrm{Q}$ cells. $E$, RT-PCR analysis of the expression of TrkA/NGF, MII, and GLAST in 20Q and 150Q cells. $F$, Western blot analysis of the expression of TrkA/NGF, p75 ${ }^{\mathrm{NTR}}$, and HAP1 in $W T, 20 \mathrm{Q}$, and $150 \mathrm{Q}$ cells. Tubulin staining served as a control.

transfection. It has been reported that chaperone (Cummings et al., 1998), proteasome (Chai et al., 1999), and transglutaminase (Igarashi et al., 1998; Kahlem et al., 1998) regulate aggregation of polyglutamine proteins. If G418 selection alters the activity of these cellular factors, it could also influence the aggregation of $150 \mathrm{Q}$ in the stably transfected cells. Nevertheless, the association between cellular defects and the diffuse nuclear localization of $150 \mathrm{Q}$ favors the idea that the nuclear localization of polyglu- 
tamine proteins is sufficient to induce cellular toxicity (Klement et al., 1998; Saudou et al., 1998).

Several cellular defects were observed in $150 \mathrm{Q}$ cells. These defects included increased cell death, susceptibility to the apoptotic agent staurosporine, abnormal morphology, and defective neurite development. Cell death could also be related to abnormal metabolism; this hypothesis is currently under investigation. The abnormal morphology and defective neurite development in $150 \mathrm{Q}$ cells are intriguing because the degeneration of neuronal processes also occurs in HD (Ferrante et al., 1985; Graveland et al., 1985; Sotrel et al., 1993). In early HD brains, we and others observed that neuropil aggregates precede the formation of intranuclear aggregates (DiFiglia et al., 1997; Gutekunst et al., 1999). The formation of neuropil aggregates in vivo could be associated with or accelerated by the degeneration of neuronal processes. The lack of normal neurite outgrowth in $150 \mathrm{Q}$ cells might reflect the dysfunction of molecules or proteins that are important for maintaining normal neuronal processes.

The most interesting finding is that the extent of cellular defects is correlated with the expression level of 150Q. First, the cell line that expresses the least 150Q has a lower death rate than do those expressing more 150Q. Second, the extent of neurite outgrowth induced by staurosporine is also inversely correlated with the expression levels of 150Q. It is possible that the cell biology of each individual cell line may not be identical and could also contribute to the variation in cellular defects. Transfection of cells using inducible expression could more accurately control the expression of transfected huntingtin and thus reveal in great detail the relationship between cellular defects and 150Q expression. The striking observation in the present study, however, is that cells expressing 150Q often have an intranuclear accumulation of huntingtin and display abnormal morphology and defective neurite outgrowth. On the other hand, $20 \mathrm{Q}$ cells in which huntingtin is mainly distributed in the cytoplasm do not show such abnormalities. Furthermore, inhibiting nuclear transport can significantly increase $20 \mathrm{Q}$ and $150 \mathrm{Q}$ in the nucleus but causes more $150 \mathrm{Q}$ cells than $20 \mathrm{Q}$ cells to die. Our study strongly supports the idea that intranuclear mutant huntingtin plays a causative role in cellular defects.

Intranuclear mutant huntingtin may interfere with gene expression in PC12 cells by its abnormal interactions with other nuclear molecules, thus leading to multiple cellular defects. Because glutamine carries polar side chains, it has been proposed that the polyglutamine domain forms polar zippers (Perutz et al., 1994). Many transcription factors contain a glutamine-rich domain, and the glutamine-rich domain of the transcription factor Sp1 can enhance its transcriptional activity (Courey and Tjian, 1988; Courey et al., 1989; Gerber et al., 1994). Thus it is also possible that the expanded polyglutamine in huntingtin affects gene transcription by competing with the glutamine-rich domains of other transcription factors for their regulation of transcriptional activities. Alternatively, expanded polyglutamine-containing huntingtin may abnormally interact with other nuclear proteins. This possibility has been suggested by the findings that SCA1 protein binds to a nuclear protein LANP (Matilla et al., 1997; Skinner et al., 1997).

Although how huntingtin acts in the nucleus remains to be investigated, our study shows that the expression of a number of transcripts is altered in $150 \mathrm{Q}$ cells. With RT-PCR, Northern blotting, and Western blotting, we have been able to confirm the altered expression of several known genes. The altered expression of these known genes is consistent with cellular defects of
$150 \mathrm{Q}$ cells. For instance, the NGF receptor mediates neurotrophin-induced neurite outgrowth. The role of HAP1 is thought to be involved in intracellular organelle transport (Gutekunst et al., 1998; S. H. Li et al., 1998a; Martin et al., 1999), which is also important for neurite development. Decreased expression in NGF receptors and HAP1 could contribute to defective neurite outgrowth. Staurosporine may partially alter or correct abnormal gene expression such that it induces neurite outgrowth of $150 \mathrm{Q}$ cells. Because metallothionein can protect cells from oxidative damage (Karin, 1985; Schwarz et al., 1995) and glutamate mediates excitotoxicity, the decreased expression of metallothionein and the increased expression of the glutamate transporter may also be associated with cell death in $150 \mathrm{Q}$ cells. The idea that intranuclear mutant huntingtin affects gene expression is also suggested by a recent study showing that HD transgenic mice have altered transcript expression of multiple neurotransmitter receptors (Cha et al., 1998). Our study substantiates this idea and additionally suggests that intranuclear huntingtin can affect gene transcription and cellular defects in the absence of aggregates. Although PC12 cells are not native neurons and the altered expression of gene transcription in this cell model may not exactly reflect the effects of mutant huntingtin in vivo, this cell model should provide a suitable approach to study the mechanism by which intranuclear huntingtin alters gene expression and induces cellular dysfunction.

\section{REFERENCES}

Andersen RD, Birren BW, Taplitz SJ, Herschman HR (1986) Rat metallothionein-1 structural gene and three pseudogenes, one of which contains 5'-regulatory sequences. Mol Cell Biol 6:302-314.

Aronin N, Chase K, Young C, Sapp E, Schwarz C, Matta N, Kornreich R, Landwehrmeyer B, Bird E, Beal MF, Vonsattel JP, Smith T, Carraway R, Boyce FM, Young AB, Penney JB, DiFiglia M (1995) CAG expansion affects the expression of mutant Huntingtin in the Huntington's disease brain. Neuron 15:1193-1201.

Becher MW, Kotzuk JA, Sharp AH, Davies SW, Bates GP, Price DL, Ross CA (1998) Intranuclear neuronal inclusions in Huntington's disease and dentatorubral and pallidoluysian atrophy: correlation between the density of inclusions and IT15 CAG triplet repeat length. Neurobiol Dis 4:387-397.

Boix J, Llecha N, Yuste VJ, Comella JX (1997) Characterization of the cell death process induced by staurosporine in human neuroblastoma cell lines. Neuropharmacology 36:811-821.

Burke JR, Enghild JJ, Martin ME, Jou YS, Myers RM, Roses AD, Vance JM, Strittmatter WJ (1996) Huntingtin and DRPLA proteins selectively interact with the enzyme GAPDH. Nat Med 2:347-350.

Carter BD, Lewin GR (1997) Neurotrophins live or let die: does p75NTR decide? Neuron 18:187-190.

Cha JH, Kosinski CM, Kerner JA, Alsdorf SA, Mangiarini L, Davies SW, Penney JB, Bates GP, Young AB (1998) Altered brain neurotransmitter receptors in transgenic mice expressing a portion of an abnormal human Huntington disease gene. Proc Natl Acad Sci USA 95:6480-6485.

Chai Y, Koppenhafer SL, Shoesmith SJ, Perez MK, Paulson HL (1999) Evidence for proteasome involvement in polyglutamine disease: localization to nuclear inclusions in SCA3/MJD and suppression of polyglutamine aggregation in vitro. Hum Mol Genet 8:673-682.

Chao MV (1992) Neurotrophin receptors: a window into neuronal differentiation. Neuron 9:583-593.

Cooper JK, Schilling G, Peters MF, Herring WJ, Sharp AH, Kaminsky Z, Masone J, Khan FA, Delanoy M, Borchelt DR, Dawson VL, Dawson TM, Ross CA (1998) Truncated N-terminal fragments of huntingtin with expanded glutamine repeats form nuclear and cytoplasmic aggregates in cell culture. Hum Mol Genet 7:783-790.

Courey AJ, Tjian R (1988) Analysis of $\mathrm{Sp} 1$ in vivo reveals multiple transcriptional domains, including a novel glutamine-rich activation motif. Cell 55:887-898.

Courey AJ, Holtzman DA, Jackson SP, Tjian R (1989) Synergistic activation by the glutamine-rich domains of human transcription factor Sp1. Cell 59:827-836. 
Cummings CJ, Mancini MA, Antalffy B, DeFranco DB, Orr HT, Zoghbi HY (1998) Chaperone suppression of aggregation and altered subcellular proteasome localization imply protein misfolding in SCA1. Nat Genet 19:148-154.

Danbolt NC (1994) The high affinity uptake system for excitatory amino acids in the brain. Prog Neurobiol 44:377-396.

Davies SW, Turmaine M, Cozens BA, DiFiglia M, Sharp AH, Ross CA, Scherzinger E, Wanker EE, Mangiarini L, Bates GP (1997) Formation of neuronal intranuclear inclusions underlies the neurological dysfunction in mice transgenic for the HD mutation. Cell 90:537-548.

DiFiglia M, Sapp E, Chase KO, Davies SW, Bates GP, Vonsattel JP, Aronin N (1997) Aggregation of huntingtin in neuronal intranuclear inclusions and dystrophic neurites in brain. Science 277:1990-1993.

Engelender S, Sharp AH, Colomer V, Tokito MK, Lanahan A, Worley P, Holzbaur EL, Ross CA (1997) Huntingtin-associated protein 1 (HAP1) interacts with the p150Glued subunit of dynactin. Hum Mol Genet 6:2205-2212.

Ferrante RJ, Kowall NW, Beal MF, Richardson Jr EP, Bird ED, Martin JB (1985) Selective sparing of a class of striatal neurons in Huntington's disease. Science 230:561-563.

Fornerod M, Ohno M, Yoshida M, Mattaj IW (1997) CRM1 is an export receptor for leucine-rich nuclear export signals. Cell 90:1051-1060.

Fukuda M, Asano S, Nakamura T, Adachi M, Yoshida M, Yanagida M, Nishida E (1997) CRM1 is responsible for intracellular transport mediated by the nuclear export signal. Nature 390:308-311.

Gerber HP, Seipel K, Georgiev O, Hofferer M, Hug M, Rusconi S, Schaffner W (1994) Transcriptional activation modulated by homopolymeric glutamine and proline stretches. Science 263:808-811.

Gollapudi L, Neet KE (1997) Different mechanisms for inhibition of cell proliferation via cell cycle proteins in PC12 cells by nerve growth factor and staurosporine. J Neurosci Res 49:461-474.

Graveland GA, Williams RS, DiFiglia M (1985) Evidence for degenerative and regenerative changes in neostriatal spiny neurons in Huntington's disease. Science 227:770-773.

Greene LA, Tischler AS (1976) Establishment of a noradrenergic clonal line of rat adrenal pheochromocytoma cells which respond to nerve growth factor. Proc Natl Acad Sci USA 73:2424-2428.

Gutekunst CA, Li SH, Yi H, Ferrante RJ, Li XJ, Hersch SM (1998) The cellular and subcellular localization of huntingtin-associated protein 1 (HAP1): comparison with huntingtin in rat and human. J Neurosci 18:7674-7686.

Gutekunst CA, Li SH, Yi H, Mulroy JS, Kuemmerle S, Jones R, Rye D, Ferrante RJ, Hersch SM, Li XJ (1999) Nuclear and neuropil aggregates in Huntington's disease: relationship to neuropathology. J Neurosci 19:2522-2534

Hackam AS, Singaraja R, Wellington CL, Metzler M, McCutcheon K, Zhang T, Kalchman M, Hayden MR (1998) The influence of huntingtin protein size on nuclear localization and cellular toxicity. J Cell Biol 141:1097-1105.

Hackam AS, Singaraja R, Zhang T, Gan L, Hayden MR (1999) In vitro evidence for both the nucleus and cytoplasm as subcellular sites of pathogenesis in Huntington's disease. Hum Mol Genet 8:25-33.

Holmberg M, Duyckaerts C, Durr A, Cancel G, Gourfinkel-An I, Damier P, Faucheux B, Trottier Y, Hirsch EC, Agid Y, Brice A (1998) Spinocerebellar ataxia type 7 (SCA7): a neurodegenerative disorder with neuronal intranuclear inclusions. Hum Mol Genet 7:913-918.

Huff K, End D, Guroff G (1981) Nerve growth factor-induced alteration in the response of PC12 pheochromocytoma cells to epidermal growth factor. J Cell Biol 88:189-198.

Igarashi S, Koide R, Shimohata T, Yamada M, Hayashi Y, Takano H, Date H, Oyake M, Sato T, Sato A, Egawa S, Ikeuchi T, Tanaka H, Nakano R, Tanaka K, Hozumi I, Inuzuka T, Takahashi H, Tsuji S (1998) Suppression of aggregate formation and apoptosis by transglutaminase inhibitors in cells expressing truncated DRPLA protein with an expanded polyglutamine stretch. Nat Genet 18:111-117.

Ishitani R, Tanaka M, Sunaga K, Katsube N, Chuang DM (1998) Nuclear localization of overexpressed glyceraldehyde-3-phosphate dehydrogenase in cultured cerebellar neurons undergoing apoptosis. Mol Pharmacol 53:701-707.

Kahlem P, Green H, Djian P (1998) Transglutaminase action imitates Huntington's disease: selective polymerization of Huntingtin containing expanded polyglutamine. Mol Cell 1:595-601.

Karin M (1985) Metallothioneins: proteins in search of function. Cell 41:9-10.

Klement IA, Skinner PJ, Kaytor MD, Yi H, Hersch SM, Clark HB,
Zoghbi HY, Orr HT (1998) Ataxin-1 nuclear localization and aggregation: role in polyglutamine-induced disease in SCA1 transgenic mice. Cell 95:41-53.

Koh JY, Wie MB, Gwag BJ, Sensi SL, Canzoniero LM, Demaro J, Csernansky C, Choi DW (1995) Staurosporine-induced neuronal apoptosis. Exp Neurol 135:153-159.

Koshy B, Matilla T, Burright EN, Merry DE, Fischbeck KH, Orr HT, Zoghbi HY (1996) Spinocerebellar ataxia type-1 and spinobulbar muscular atrophy gene products interact with glyceraldehyde-3phosphate dehydrogenase. Hum Mol Genet 5:1311-1318.

Kudo N, Khochbin S, Nishi K, Kitano K, Yanagida M, Yoshida M, Horinouchi S (1997) Molecular cloning and cell cycle-dependent expression of mammalian CRM1, a protein involved in nuclear export of proteins. J Biol Chem 272:29742-29751.

Lah JJ, Burry RW (1993) Neuronotypic differentiation results in reduced levels and altered distribution of synaptophysin in PC12 cells. J Neurochem 60:503-512.

Li H, Ohishi H, Kinoshita A, Shigemoto R, Nomura S, Mizuno N (1997) Localization of a metabotropic glutamate receptor, mGluR7, in axon terminals of presumed nociceptive, primary afferent fibers in the superficial layers of the spinal dorsal horn: an electron microscope study in the rat. Neurosci Lett 223:153-156.

Li M, Miwa S, Kobayashi Y, Merry DE, Yamamoto M, Tanaka F, Doyu M, Hashizume Y, Fischbeck KH, Sobue G (1998) Nuclear inclusions of the androgen receptor protein in spinal and bulbar muscular atrophy. Ann Neurol 44:249-254.

Li SH, Li XJ (1998) Aggregation of N-terminal huntingtin is dependent on the length of its glutamine repeats. Hum Mol Genet 7:777-782.

Li SH, Gutekunst CA, Hersch SM, Li XJ (1998a) Interaction of huntingtin-associated protein with dynactin P150Glued. J Neurosci 18:1261-1269.

Li SH, Hosseini SH, Gutekunst CA, Hersch SM, Ferrante RJ, Li XJ (1998b) A human HAP1 homologue. Cloning, expression, and interaction with huntingtin. J Biol Chem 273:19220-19227.

Li XJ, Li SH, Sharp AH, Nucifora Jr FC, Schilling G, Lanahan A, Worley P, Snyder SH, Ross CA (1995) A huntingtin-associated protein enriched in brain with implications for pathology. Nature 378:398-402.

MacDonald ME, Gusella JF (1996) Huntington's disease: translating a CAG repeat into a pathogenic mechanism. Curr Opin Neurobiol 6:638-643.

Mangiarini L, Sathasivam K, Seller M, Cozens B, Harper A, Hetherington C, Lawton M, Trottier Y, Lehrach H, Davies SW, Bates GP (1996) Exon 1 of the HD gene with an expanded CAG repeat is sufficient to cause a progressive neurological phenotype in transgenic mice. Cell 87:493-506.

Martin EJ, Kim M, Velier J, Sapp E, Lee HS, Laforet G, Won L, Chase K, Bhide PG, Heller A, Aronin N, Difiglia M (1999) Analysis of Huntingtin-associated protein 1 in mouse brain and immortalized striatal neurons. J Comp Neurol 403:421-430.

Martindale D, Hackam A, Wieczorek A, Ellerby L, Wellington C, McCutcheon K, Singaraja R, Kazemi-Esfarjani P, Devon R, Kim SU, Bredesen DE, Tufaro F, Hayden MR (1998) Length of huntingtin and its polyglutamine tract influences localization and frequency of intracellular aggregates. Nat Genet 18:150-154.

Matilla A, Koshy BT, Cummings CJ, Isobe T, Orr HT, Zoghbi HY (1997) The cerebellar leucine-rich acidic nuclear protein interacts with ataxin-1. Nature 389:974-978.

Meakin SO, Suter U, Drinkwater CC, Welcher AA, Shooter EM (1992) The rat trk protooncogene product exhibits properties characteristic of the slow nerve growth factor receptor. Proc Natl Acad Sci USA 89:2374-2378

Moulder KL, Onodera O, Burke JR, Strittmatter WJ, Johnson Jr EM (1999) Generation of neuronal intranuclear inclusions by polyglutamine-GFP: analysis of inclusion clearance and toxicity as a function of polyglutamine length. J Neurosci 19:705-715.

Ordway JM, Tallaksen-Greene S, Gutekunst CA, Bernstein EM, Cearley JA, Wiener HW, Dure LS, Lindsey R, Hersch SM, Jope RS, Albin RL, Detloff PJ (1997) Ectopically expressed CAG repeats cause intranuclear inclusions and a progressive late onset neurological phenotype in the mouse. Cell 91:753-763.

Ossareh-Nazari B, Bachelerie F, Dargemont C (1997) Evidence for a role of CRM1 in signal-mediated nuclear protein export. Science 278:141-144.

Paulson HL, Perez MK, Trottier Y, Trojanowski JQ, Subramony SH, Das SS, Vig P, Mandel JL, Fischbeck KH, Pittman RN (1997) Intranuclear 
inclusions of expanded polyglutamine protein in spinocerebellar ataxia type 3. Neuron 19:333-344.

Perutz MF, Johnson T, Suzuki M, Finch JT (1994) Glutamine repeats as polar zippers: their possible role in inherited neurodegenerative diseases. Proc Natl Acad Sci USA 91:5355-5358.

Radeke MJ, Misko TP, Hsu C, Herzenberg LA, Shooter EM (1987) Gene transfer and molecular cloning of the rat nerve growth factor receptor. Nature 325:593-597.

Raffioni S, Bradshaw RA (1995) Staurosporine causes epidermal growth factor to induce differentiation in $\mathrm{PC} 12$ cells via receptor up-regulation. J Biol Chem 270:7568-7572.

Reddy PS, Housman DE (1997) The complex pathology of trinucleotide repeats. Curr Opin Cell Biol 9:364-372.

Ross CA (1997) Intranuclear neuronal inclusions: a common pathogenic mechanism for glutamine-repeat neurodegenerative diseases? Neuron 19:1147-1150.

Saudou F, Finkbeiner S, Devys D, Greenberg ME (1998) Huntingtin acts in the nucleus to induce apoptosis but death does not correlate with the formation of intranuclear inclusions. Cell 95:55-66.

Saunders PA, Chen RW, Chuang DM (1999) Nuclear translocation of glyceraldehyde-3-phosphate dehydrogenase isoforms during neuronal apoptosis. J Neurochem 72:925-932.

Sawa A, Khan AA, Hester LD, Snyder SH (1997) Glyceraldehyde-3phosphate dehydrogenase: nuclear translocation participates in neuronal and nonneuronal cell death. Proc Natl Acad Sci USA 94: 11669-11674.

Schwarz MA, Lazo JS, Yalowich JC, Allen WP, Whitmore M, Bergonia HA, Tzeng E, Billiar TR, Robbins PD, Lancaster Jr JR, Pitt BR (1995) Metallothionein protects against the cytotoxic and DNA-damaging effects of nitric oxide. Proc Natl Acad Sci USA 92:4452-4456.

Sittler A, Wälter S, Wedemeyer N, Hasenbank R, Scherzinger E, Eickhoff H, Bates GB, Lehrach H, Wanker E (1998) SH3GL3 associates with the huntingtin exon 1 protein and promotes the formation of polyglncontaining protein aggregates. Mol Cell 2:427-436.

Skinner PJ, Koshy BT, Cummings CJ, Klement IA, Helin K, Servadio A,
Zoghbi HY, Orr HT (1997) Ataxin-1 with an expanded glutamine tract alters nuclear matrix-associated structures. Nature 389:971-974.

Sotrel A, Williams RS, Kaufmann WE, Myers RH (1993) Evidence for neuronal degeneration and dendritic plasticity in cortical pyramidal neurons of Huntington's disease: a quantitative Golgi study. Neurology 43:2088-2096.

Tait D, Riccio M, Sittler A, Scherzinger E, Santi S, Ognibene A, Maraldi NM, Lehrach H, Wanker EE (1998) Ataxin-3 is transported into the nucleus and associates with the nuclear matrix. Hum Mol Genet 7:991-997.

Tanaka K (1993) Cloning and expression of a glutamate transporter from mouse brain. Neurosci Lett 159:183-186.

Tischler AS, Ruzicka LA, Perlman RL (1990) Mimicry and inhibition of nerve growth factor effects: interactions of staurosporine, forskolin, and K252a in PC12 cells and normal rat chromaffin cells in vitro. J Neurochem 55:1159-1165.

Tischler AS, Ruzicka LA, Dobner PR (1991) A protein kinase inhibitor, staurosporine, mimics nerve growth factor induction of neurotensin/ neuromedin N gene expression. J Biol Chem 266:1141-1146.

Trottier Y, Lutz Y, Stevanin G, Imbert G, Devys D, Cancel G, Saudou F, Weber C, David G, Tora L, Agid Y, Brice A, Mandel J (1995) Polyglutamine expansion as a pathological epitope in Huntington's disease and four dominant cerebellar ataxias. Nature 378:403-406.

Tso JY, Sun XH, Kao TH, Reece KS, Wu R (1985) Isolation and characterization of rat and human glyceraldehyde-3-phosphate dehydrogenase cDNAs: genomic complexity and molecular evolution of the gene. Nucleic Acids Res 13:2485-2502.

Wolff B, Sanglier JJ, Wang Y (1997) Leptomycin B is an inhibitor of nuclear export: inhibition of nucleo-cytoplasmic translocation of the human immunodeficiency virus type 1 (HIV-1) Rev protein and Revdependent mRNA. Chem Biol 4:139-147.

Yao R, Yoshihara M, Osada H (1997) Specific activation of a c-Jun NH2-terminal kinase isoform and induction of neurite outgrowth in PC-12 cells by staurosporine. J Biol Chem 272:18261-18266. 